\title{
O DWÓCH TYPACH RANDOMIZACJI W DECYZJACH DYSTRYBUCYJNYCH
}

\author{
Wojciech Załuski* \\ Uniwersytet Jagielloński
}

Streszczenie: Celem artykułu jest analiza porównawcza dwóch typów randomizacji - egalitarnej (RE) i proporcjonalnej $(R P)$ - jako metod podejmowania decyzji dystrybucyjnych. Zmierza ona do określenia warunków, w jakich dopuszczalne jest ich zastosowanie. W artykule bronione sq następujace tezy: że racje sprawiedliwościowe za stosowaniem $R E$ należy rozumieć szeroko (obejmując tym pojęciem nie tylko sytuacje indyferencji - równego spetniania kryterium podziatu - ale także braku kryteriów podziału lub ich niewspótmierności) $i$ ze sq one silniejsze niż racje utylitarystyczne; ze z uwagi na konflikt między sprawiedliwościq ex ante i ex post, który może przybrać ostra postać tylko w kontekście RP, RP może być stosowana stosunkowo rzadko - wytącznie w dwóch sytuacjach: wielokrotnej powtarzalności dystrybucji i/lub zachodzenia niewielkiej różnicy w roszczeniach kandydatów do danego dobra/ciężaru. W artykule wskazuje się także na inne różnice między RP i RE, między innymi taka, że RP musi mieć zawsze charakter statystyczny, natomiast RE może mieć niekiedy charakter epistemiczny, oraz zwraca się uwage na to, że w pewnych sytuacjach (np. w tzw. Number Problem) moga pojawić się watpliwości, czy należy zastosować RE, czy $R P$, i ich zastosowanie może okazać się równoważne.

Stowa kluczowe: sprawiedliwość, racje normatywne, racje psychologiczne, randomizacja egalitarna, randomizacja proporcjonalna, utylitaryzm, the Number Problem.

\section{ON TWO TYPES OF RANDOMIZATION IN DISTRIBUTIVE DECISIONS}

Abstract: The purpose of the article is to provide a comparative analysis of two types of randomization - egalitarian and proportional - in distributive decisions, with a view to determining conditions in which they can be applied. It is argued in the article that justice reasons in favour of egalitarian randomization

* Wojciech Załuski, Katedra Filozofii Prawa i Etyki Prawniczej Wydział Prawa i Administracji Uniwersytet Jagielloński, ul. Bracka 12, 31-007 Kraków, zaluskiwojciech@gmail.com 
should be construed broadly (as embracing not only the situation of indifference - the equal satisfaction of a given criterion, but also the situations of the lack of criteria or their incommensurability), and that they are stronger than utilitarian reasons. It is also argued that the conflict between justice ex ante and justice ex post may take an acute form only in the case of proportional randomization, which is why this type of randomization can be applied relatively rarely - only in two situations: if the distribution is repeatedly made and/or if the differences between claims of the candidates (for a good/burden being distributed) are not substantial. Some other differences are also pointed out in the article, e.g., that while proportional randomization must always be statistical, egalitarian randomization may be at times epistemic. It is also argued that in some circumstances (e.g., in the context of the so called Number Problem) doubts may arise as to which type of randomization should be applied, and the applications of both types may prove to be equivalent.

Key words: justice, normative reasons, psychological reasons, egalitarian randomization, proportional randomization, utilitarianism, the Number Problem.

\section{RANDOMIZACJA EGALITARNA A RANDOMIZACJA PROPORCJONALNA}

Celem niniejszego artykułu jest analiza wybranych filozoficznych zagadnień związanych ze stosowaniem dwóch typów randomizacji - egalitarnej (dalej: RE) i proporcjonalnej (dalej: RP) - jako metod podejmowania decyzji dystrybucyjnych. Zanim przejdę do prezentacji tych problemów, przedstawię zwięźle oba typy randomizacji. Pierwszy polega na stosowaniu mechanizmu losowego z równomiernym rozkładem szans, a więc na przyjęciu, że każdy z kandydatów do uzyskania dobra/ciężaru ma jednakowe (równe) prawdopodobieństwo otrzymania owego dobra/ciężaru. Natomiast RP polega na stosowaniu mechanizmu losowego z szansami „ważonymi”, przy czym wagi przydzielone poszczególnym kandydatom są proporcjonalne do stopnia spełnienia przez nich określonego (właściwego dla danej dystrybucji) kryterium sprawiedliwości ${ }^{1}$. Rzecz jasna, randomizacja nie-egalitarna nie musi być RP: można sobie wyobrazić np. „przewrotną” lub „chaotyczną” jej wersję; pierwsza przyzna-

Przyjmuję klasyczne rozróżnienie między sprawiedliwością ogólną i jej kryteriami. Sprawiedliwość ogólna polega na świadczeniu każdemu tego, co mu się należy (suum cuique tribuere). Jest to sformułowanie blankietowe, które wymaga doprecyzowania tego, co się komu należy. Dostarczają go tzw. kryteria sprawiedliwości, np. potrzeby, wysiłku, pracy, zasługi itd., które prowadzą do określonych „formuł sprawiedliwości” (np. „każdemu według potrzeb” itd.). Por. na ten temat zwłaszcza Perelman, 1963. 
wałaby wagi odwrotnie proporcjonalne do siły roszczeń ${ }^{2}$, druga byłaby drugim etapem loterii, której pierwszym byłaby RE przydzielająca wagi losowo, niezależnie od siły roszczeń. Te warianty randomizacji nie-egalitarnej nie mogą być jednak nawet „wstępnie” uznane za możliwą procedurę sprawiedliwej dystrybucji, z uwagi na to, iż naruszają zasadę proporcjonalności (nakazującą dystrybucję dóbr/ciężarów stosownie, tj. właśnie proporcjonalnie do siły roszczeń), nie oferując w zamian nawet prima facie etycznie przekonującej alternatywnej metody. Nie przesądzam, że RP jest jedyna rozsądną metodą dystrybucji losowej w przypadku nierównych roszczeń ${ }^{3}$. Natomiast jest bezsprzecznie metodą przynajmniej prima facie etycznie akceptowalną i przez to zasługującą na pogłębioną analizę. Przejdę teraz do wskazania problemów filozoficznych, jakie wiążą się ze stosowaniem obu metod.

Pierwszy problem - może raczej quasi-filozoficzny niż filozoficzny - dotyczy charakteru dóbr, jakie mogą być dystrybuowane za pomocą mechanizmów losowych. Jest on stosunkowo łatwy do rozwiązania. Wydaje się bowiem, że ogólnym warunkiem (koniecznym, ale niewystarczającym) stosowania RE i RP jest to, aby dystrybucja dotyczyła dóbr/ciężarów niepodzielnych, tzn. takich, których nie da się podzielić (np. miejsca w parlamencie), albo których podział prowadziłby do utraty ich wartości (np. narządy do przeszczepu, samochód). Jeśli bowiem dystrybuowane dobro/ciężar jest podzielne, należy podzielić je między kandydatów (równo - jeśli relewantne kryterium sprawiedliwości spełniają w równym stopniu, lub proporcjonalnie do stopnia spełnienia przez nich relewantnego kryterium sprawiedliwości - jeśli spełniają je w nierównym stopniu). Jest tak przede wszystkim dlatego, iż właściwym przedmiotem dystrybucji jest samo dobro/ciężar, a nie szanse jego otrzymania ${ }^{4}$. Inny argument za zasadnością stosowania randomizacji wyłącznie wtedy, gdy dobro jest niepodzielne, wiąże się z możliwością pojawienia się konfliktu między sprawiedliwością ex ante (tj.

2 Siła roszczenia zależy od stopnia spełniania przez kandydata właściwego dla danego problemu dystrybucyjnego kryterium sprawiedliwości.

3 W szczególności interesującym problemem jest możliwość wykorzystania przy losowym podejmowaniu decyzji talmudycznej reguły spornej szaty (contested garment rule), alternatywnej wobec zasady proporcjonalności. Wedle mojej wiedzy ten problem nie był dotychczas badany. Ciekawe jest zwłaszcza to, czy w kontekście losowej dystrybucji reguła ta mogłaby być zastosowana tylko na pierwszym etapie (przydzielania kandydatom do niepodzielnego dobra jego „abstrakcyjnych” części, a więc szans jego uzyskania), zaś na drugim etapie (losowej dystrybucji) stosowana byłaby już RP; czy także na drugim etapie można byłaby znaleźć jakiś wariant reguły spornej szaty różniący się od RP. Jeśli pierwsza alternatywa jest prawdziwa, oznaczałoby to, że w kontekście losowej dystrybucji reguła spornej szaty nie generuje odrębnej procedury, lecz musi odwoływać się do RP. Na temat samej reguły spornej szaty por. np. Peyton Young, 1995, s. 64-89, oraz Załuski, 2014.

4 Oczywiście łatwo można wyobrazić sobie randomizację także w odniesieniu do podzielnych dóbr. Załóżmy np., że dwie osoby mają równe roszczenia do jednego (podzielnego) dobra. Naturalną dystrybucją byłaby taka, która przydziela każdej osobie po połowie dobra. Da się tu jednak zastosować także mechanizm losowy: każda z dwóch osób otrzymuje wówczas całe dobro z prawdopodobieństwem równym 1/2. W takiej sytuacji mechanizm ten jest jednak "nienaturalny" - jego zastosowanie byłoby przejawem fetyszyzacji metod losowych, zapoznania faktu, że właściwym przedmiotem dystrybucji jest dobro, a nie szanse jego uzyskania. 
przed dokonaniem przydziału dobra/ciężaru, dotyczącą samej procedury), i sprawiedliwością ex post (tj. po przydzieleniu dobra/ciężaru, dotyczącą wyniku procedury). Otóż możliwość ta pojawia się wyłącznie w kontekście randomizacji, a nie równego/ proporcjonalnego podziału samego dobra/ciężaru (przy tym ostatnim nie występuje bowiem charakterystyczna dla randomizacji dwuetapowość dystrybucji - najpierw samych szans, a potem - w zależności od wyniku losowania - samego dobra; dystrybucji podlega od razu i tylko dobro). Konflikt ten jest wprawdzie wyraźniejszy i normatywnie bardziej istotny w przypadku RP, dotyczy jednak również RE (powrócę do tego wątku w punktach 4 i 5, rozjaśniając między innymi pojęcie „normatywnej istotności" konfliktu). W każdym razie, w sytuacjach, w których konfliktu tego można uniknąć, a więc w przypadku dystrybucji dobra czy dóbr podzielnych, nie należy go stwarzać, stosując probabilistyczną metodę dystrybucji.

Drugi problem filozoficzny - głębszy i ciekawszy - dotyczy racji przemawiających za zastosowaniem RE i RP w kontekście dystrybucji dóbr/ciężarów (niepodzielnych). Jeśli chodzi o racje przemawiające za RE, poświęcono im sporo uwagi w literaturze (por. np. Broome, 1984; Elster, 1987), niemniej podział tych racji zaproponowany w niniejszym artykule (w punkcie 2) na sprawiedliwościowe i utylitarystyczne, a zwłaszcza sposób ich zdefiniowania, ma, jak się wydaje, charakter w jakimś stopniu nowatorski. W punkcie tym ocenię także „siłę” tych racji. Punkt 3 będzie poświęcony racjom przemawiającym za zastosowaniem RP. Jest to zagadnienie słabo opracowane w literaturze, omawiane raczej „przy okazji” rozważań dotyczących RE (por. np. Broome, 1984, s. 48) lub pewnych szczegółowych dylematów moralnych, jak np. tzw. Number Problem (dotyczący zasadności uwzględniania liczebności grup przy podejmowaniu decyzji o tym, którą z nich należy uratować). Przedstawię pewną propozycję normatywną określającą warunki, w jakich RP jest dopuszczalna, a także przeprowadzę porównawczą analizę RE i RP, uwzględniając poza tym szczególną „rozwarstwioną" (stratified) - wersję RP. W ostatnim punkcie omówię zastosowanie RE i RP w kontekście wspomnianego Number Problem.

Na zakończenie tych wstępnych uwag chciałbym zwrócić uwagę na jeszcze jedną kwestię. Ze względu na przyjętą w nim perspektywą badawczą (analiza filozoficzna) niniejszy artykuł jest komplementarny wobec bogatej polskiej literatury na temat metod losowej dystrybucji, analizującej ją najczęściej z odmiennej perspektywy - teorii wyboru społecznego ${ }^{5}$. Przyjęcie tej ostatniej perspektywy przesądza, że analizy mają charakter matematyczny i koncentrują się przede wszystkim na zbadaniu, czy określone procedury probabilistycznego podziału posiadają pewne pożądane własności, np. optymalności w sensie Pareto, wolności od zazdrości czy odporności na zachowania strategiczne (por. zwłaszcza Szaniawski, 1966; Szaniawski, 1975; Szaniawski,

5 Wyjątkiem jest tutaj krótki artykuł Grzegorza Lissowskiego (2006a), poświęcony etycznym aspektom losowych metod podziału i zawierający także wzmiankę o Number Problem, który nie jest jednak dokładniej analizowany. 
1979; Lissowski, 1992; Lissowski, 2006b; Bożykowski, 2012). Analizy te - z uwagi na przyjętą perspektywę teorii wyboru społecznego - opierają się na dwóch założeniach: uczestnicy dystrybucji („kandydaci”) mają ściśle określone preferencje ${ }^{6}$ na rozdzielanych dobrach (a więc tworzą ich „rankingi”) i preferencje te są jedyną informacją o „kandydatach” istotną dla podejmowanej decyzji o dystrybucji. Z jednej strony, założenia te pozwalają na ścisłą analizę procedur losowej dystrybucji, prowadzącą do szeregu ważnych twierdzeń (artykuły badaczy z kręgu teorii wyboru społecznego odznaczają się wyrafinowaniem matematycznym), z drugiej jednak ograniczają zakres tych twierdzeń ${ }^{7}$, przynajmniej w tym sensie, że wyraźnie separują je od filozoficznych analiz sprawiedliwości dystrybutywnej. W tych ostatnich bowiem zwykle odrzuca się drugie założenie (i, w rezultacie, pierwsze uznaje się za irrelewantne $)^{8}$, przyjmując, iż o dystrybucji decydują takie czy inne kryteria sprawiedliwości (zasługi, wysiłku, wyniku, wysokości prawnego roszczenia, potrzeby, stopnia winy, wielkości wyrządzonej szkody itp.), a nie preferencje kandydatów (tzn. użyteczności, jakie przypisują określonym dobrom/ciężarom) ${ }^{9}$. Trudno natomiast orzec, czy w praktyce częściej występują problemy dystrybucyjne, w odniesieniu do których właściwe jest podejście, jak je nazwałem, „filozoficzne”, odwołujące się do innych kryteriów niż preferencje kandydatów, czy też problemy, wobec których właściwe jest podejście typowe dla teorii wyboru społecznego, a więc takie, które nakazuje traktować profile uporządkowań preferencyjnych kandydatów jako kluczową lub co najmniej istotną informację. Nie

6 Zwykle (choć nie zawsze) przyjmuje się, że chodzi o preferencje porządkowe (a nie kardynalne), tzn. takie, które pozwalają uporządkować dzielone dobra od najmniej do najbardziej pożądanego (utworzyć ich ranking), ale nie dostarczają informacji o różnicach w sile pożądania przez kandydata dystrybuowanych dóbr.

7 Przykładowo, Klemens Szaniawski $(1966,1975)$, opierając się na tych założeniach, dokonał dwóch ważnych ustaleń: (1) iż można wyróżnić co najmniej dwa ujęcia egalitarnej randomizacji: jako równości szans satysfakcji (przy której każdy z uczestników dystrybucji ma takie samo prawdopodobieństwo uzyskania dobra, które zajmuje takie samo miejsce w ich osobistych rankingach dystrybuowanych dóbr), i równości szans wyboru (przy której każdy z uczestników dystrybucji ma taką samą szansę (prawdopodobieństwo), że będzie wybierał jako $k$-ty jeden z możliwych podziałów dystrybuowanych dóbr; (2) iż procedura równości szans satysfakcji może prowadzić do naruszeń nawet najsłabszej wersji zasady optymalności w sensie Pareto, tzn. takiej, która wymaga, aby wybrana alokacja nie była słabo zdominowana przez jakąś inną (alokacja $a$ jest słabo zdominowana przez alokację $b$ wtedy i tylko wtedy, jeśli jest mniej preferowana niż $b$ przez co najmniej jednego z uczestników dystrybucji, i nie jest bardziej preferowana niż $b$ przez żadnego z uczestników dystrybucji). Ustalenia te są jednak w tym sensie ograniczone, że odnoszą się wyłącznie do sytuacji, w których spełnione są oba założenia. Oznacza to, że fakt, iż pierwsza procedura randomizacji zaproponowana przez Szaniawskiego może naruszać zasadę optymalności w sensie Pareto, nie stanowi żadnego argumentu przeciw RE tak rozumianej jak w niniejszym tekście, tzn. jako procedury stosowanej w sytuacjach, gdy same preferencje kandydatów uznaje się za nieistotne dla decyzji dystrybucyjnej (a uznaje się za istotne różne kryteria sprawiedliwości). Na marginesie zauważmy także, że w sytuacjach, w których dystrybuuje się jedno dobro niepodzielne lub wiele dóbr niepodzielnych, ale jednorodnych/identycznych (w tych sytuacjach rankingi uczestników wyboru są identyczne), konflikt między procedurą równości szans satysfakcji i zasadą optymalności w sensie Pareto nie może wystąpić.

8 Zakłada się jedynie, by tak rzec, „ogólną preferencję” kandydata - że pragnie otrzymać określony przedmiot dystrybucji, gdy ów przedmiot jest dobrem, i nie pragnie go otrzymać, gdy jest ciężarem.

9 Choć siła tych ostatnich może posłużyć do eksplikacji mglistego pojęcia potrzeby. Ale i tu jednak pojawiają się pewne filozoficzne problemy, które są zwykle pomijane w matematycznych analizach (piszę o tym więcej w punkcie 2). 
dysponując odpowiednimi statystykami, nie sposób a priori rozstrzygnąć tego proble$\mathrm{mu}$. Zresztą problem ten jest w gruncie rzeczy mało istotny; ważne jest to, że, z całą pewnością, w praktyce występują oba rodzaje problemów dystrybucyjnych, co uzasadnia tezę, że oba podejścia - filozoficzne i teorii wyboru społecznego - są potrzebne i komplementarne. Zarzut ograniczenia uniwersalności twierdzeń sformułowany wyżej pod adresem podejścia właściwego dla teorii wyboru społecznego jest więc równie uzasadniony w stosunku do rozważań na temat sprawiedliwości prowadzonych z perspektywy filozoficznej. Ograniczenia obu podejść dotyczą zresztą nie tylko tego, że każde z nich wskazuje na odmienne informacje o kandydatach jako kluczowe dla podjęcia decyzji dystrybucyjnej, ale także tego, że w konkretnych analizach prowadzonych w ramach obu podejść przyjmuje się różnorakie uproszczenia struktury sytuacji dystrybucyjnych. Tego rodzaju uproszczenie przyjmuję także w moich rozważaniach, pomijając pewien typ sytuacji dystrybucji dóbr niepodzielnych (gdyż tylko takich, jak argumentowałem, może dotyczyć randomizacja). Ściśle bowiem rzecz biorąc, możemy wyobrazić sobie trzy różne sytuacje dystrybucji tego rodzaju dóbr: (1) gdy jedno dobro niepodzielne dystrybuowane jest między co najmniej dwie osoby; (2) gdy $m$ jednorodnych dóbr niepodzielnych jest dystrybuowanych między $n$ osób, przy czym $m>1, n>m$; (3) gdy $m$ dóbr niepodzielnych jest dystrybuowanych między $n$ osób, przy czym $m>1, n>m$, i co najmniej dwa z dystrybuowanych dóbr mają charakter odmienny - są różnorodne (np. samochód i wycieczka dookoła świata). Moje dalsze analizy RP i RE dotyczą jednak wyłącznie sytuacji (1) i (2). Takie ograniczenie jest przyjmowane zwykle, choć rzadko wyrażone wprost, w filozoficznych rozważaniach na temat randomizacji (por. np. Broome, 1984). Ten fakt oczywiście nie uzasadnia jeszcze jego wprowadzenia. Jednak inny fakt - iż wiele realnych przykładów stosowania losowych metod dystrybucji dotyczy właśnie sytuacji (1) i (2) - już takiego uzasadnienia dostarcza ${ }^{10}$.

10 Anonimowy recenzent ma wątpliwości, czy rzeczywiście wiele problemów dystrybucyjnych można skategoryzować jako sytuacje (1) i (2). Przyznaje on, że np. losowa dystrybucja mandatów do parlamentu podpada pod te sytuacje (ściślej: sytuację (2)), ale twierdzi, że dystrybucja nerek (czy innych narządów) do przeszczepu, z uwagi na ich różnorodność, już nie. Trudno mi się z tym zgodzić. Uważam, że recenzent przyjmuje zbyt rygorystyczną definicję jednorodności dystrybuowanych dóbr (jako identyczności). Sądzę, iż dobra mogą być uznane za jednorodne już wtedy, gdy w kontekście dokonywanej dystrybucji spełniają swoją funkcję równie dobrze albo przynajmniej niemal równie dobrze. Wydaje się, że np. większość narządów do przeszczepu spełnia tę - nazwę ją "funkcjonalną" - definicję jednorodności. Zauważmy, że już sam fakt, iż problem dystrybucji organów na cele przeszczepu można ująć w kategorii analizowanych w tym tekście sytuacji (1) i (2), pokazuje, że okoliczności te są praktycznie istotne. Inne przykłady, które można zaliczyć do tych sytuacji, prezentuję w dalszej części artykułu, zwłaszcza w punkcie 2. Zgadzam się jednak z recenzentem w innej kwestii, mianowicie iż w wielu sytuacjach konieczne może być uwzględnienie nie tylko kryterium „etycznego" (zasługi, pracy itd.), lecz także preferencji. Oto przykład recenzenta. Załóżmy, że mamy dwóch uczestników podziału dwóch dóbr: domku letniskowego i samochodu. Obaj mają identyczne uprawnienia do obu dóbr, ale jeden preferuje domek, a drugi - samochód. W tym przypadku pomijanie preferencji uczestników podziału byłoby oczywiście niewłaściwe. Sytuacje tego rodzaju (podziału dóbr niepodzielnych i niejednorodnych) pomijam jednak w swoich analizach. Jest to świadome ograniczenie zakresu moich analiz. Przykład recenzenta jest ciekawy także z innego powodu; pokazuje mianowicie, że niekiedy konieczne może być uwzględnienie zarówno kryteriów etycznych dystrybucji, jak i kryterium preferencji. Komplementar- 


\section{RACJE ZA ZASTOSOWANIEM RANDOMIZACJI EGALITARNEJ}

Przed dokonaniem analizy racji za zastosowaniem RE i RP chciałbym poczynić trzy uwagi wstępne.

Po pierwsze, należy dokonać rozróżnienia między sensem danej metody randomizacji i szczegótowa racją normatywnq za jej przyjęciem. Otóż sensem RE jest dawanie wyrazu zasadzie egalitarnej; RE czyni to w taki sposób, iż przyznaje każdemu kandydatowi równą szansę uzyskania określonego dobra/poniesienia określonego ciężaru. Natomiast sensem RP jest dawanie wyrazu zasadzie proporcjonalności, co RP czyni w ten sposób, iż daje każdemu kandydatowi proporcjonalną do siły jego roszczenia szansę uzyskania określonego dobra/poniesienia określonego ciężaru ${ }^{11}$. Sens RP i RE można jednak ująć nieco inaczej: twierdząc, że jest nim wyłączenie możliwości przywoływania jakichkolwiek racji w toku podejmowania decyzji dystrybucyjnych. To wyłączanie wszystkich racji ma eliminować oczywiście „złe” racje (stronnicze, wynikające z przesądów itd.), tzn. randomizacja ma spełniać funkcję „uzdrawiającą” (sanitizing) (por. Stone, 2009), niemniej randomizacja może jednak wyłączać także „dobre” racje (jeśli takie istnieją dla danej sytuacji dystrybucyjnej). Od sensu randomizacji (dwojako rozumianego: jako dawanie wyrazu metodą losową określonym zasadom etycznym i jako wyłączanie możliwości przywoływania racji) należy odróżnić szczegótowe racje normatywne za jej zastosowaniem, wskazujące okoliczności, w jakich RE lub RP jest uzasadniona. Konieczność tego rodzaju szczegółowych racji można najłatwiej uzasadnić, korzystając z wprowadzonych wyżej dwóch rozumień sensu randomizacji jako metody dystrybucji. Pierwsze rozumienie sensu samo z siebie uzasadnia prima facie RE i RP, wskazuje bowiem na to, że realizują one określone zasady etyczne ${ }^{12}$. Drugie rozumienie idzie jednak w przeciwnym kierunku: wskazuje bowiem na to, że randomizacja wyłącza możliwość przywołania jakichkolwiek racji, co, nawet jeśli weźmie się pod uwagę cel owego wyłączenia - eliminację złych racji -

ność podejścia filozoficznego i teorii wyboru społecznego może się więc przejawiać nie tylko w tym, że są one właściwe dla różnych typów dystrybucji, ale także na poziomie analizy jednego/tego samego problemu dystrybucyjnego (choć, w tym ostatnim przypadku, zawsze, jak się wydaje, jedno z kryteriów musi zostać uznane za podstawowe; w przykładzie recenzenta jest nim kryterium etyczne; gdyby obaj kandydaci mieli różne roszczenia, ich preferencje byłyby mniej istotne lub zupełnie nieistotne - kandydat, którego roszczenie byłoby dużo silniejsze, uzyskałby także dobro dużo silniej preferowane przez drugiego kandydata).

11 Można powiedzieć, używając określenia Broome’a (1990, s. 100), że w obu przypadkach dawanie wyrazu określonej zasadzie etycznej polega na „zastępczej satysfakcji” (surrogate satisfaction) roszczeń, w której sprawiedliwa dystrybucja dobra niepodzielnego zastępuje sprawiedliwa dystrybucja szans jego uzyskania. Rzecz jasna, zwycięzca loterii, poza „zastępczą satysfakcją”, będzie miał również satysfakcję, którą można nazwać „rzeczywistą”. Termin Broome'a - „zastępcza satysfakcja” - może być więc o tyle mylący, że sugeruje, iż właśnie "zastępuje” ona rzeczywistą satysfakcję.

12 W swoich rozważaniach pomijam problem kontraktualistycznych uzasadnień randomizacji w decyzjach dystrybucyjnych; por. na ten temat np. Saunders, 2008. 
wydaje się być antytezą racjonalnej procedury dystrybucyjnej ${ }^{13} \mathrm{i}$ jako takie wymaga dodatkowego uzasadnienia, tym bardziej że randomizacja może także, jak już wspomniano, wyłączać dobre racje. Uzasadnienie to zmierza więc, ogólnie rzecz biorąc, do wykazania, że randomizacja nie wyłacza dobrych racji.

Po drugie, prowadzona przeze mnie analiza randomizacji jako metody podejmowania decyzji dystrybucyjnych dotyczy przede wszystkim tzw. sprawiedliwości lokalnej czy „mikro-sprawiedliwości' (por. np. Peyton-Young, 1995, s. 6-7); pomijam trzy główne kwestie pojawiające się w związku z problematyką "przypadku” w filozoficznych teoriach „makro-sprawiedliwości”, mianowicie: Na ile instytucje społeczne powinny przeciwdziałać wpływowi przypadku („genetycznego” czy „społecznego”) na nasz „życiowy sukces”? (por. np. Rawls, 1971; Fishkin, 1984); W jakim stopniu, jeśli w ogóle, społeczeństwa merytokratyczne (tj. takie, w których różnego rodzaju dobra przyznaje się wedle zasług i minimalizuje się wpływ przypadku na ich uzyskanie) przyczyniają się do wzrostu poziomu zawiści i obniżenia szacunku dla samego siebie wśród osób znajdujących się na niższych szczeblach drabiny społecznej? (por. np. Young, 1961, oraz Schoeck, 1987); wreszcie - Jak wyglądałoby i jakie miałoby wady i zalety „społeczeństwo aleatoryjne” (aleatorian society), tj. takie, w którym wszystkie dobra i ciężary byłyby dystrybuowane za pomocą (egalitarnych) loterii (por. Goodwin, 2005).

Po trzecie, należy rozróżnić racje normatywne uzasadniające zastosowanie randomizacji od pewnych „okoliczności” czy racji psychologicznych sprawiających, że ludzie uważają dana postać metody randomizacji za bardziej sprawiedliwą w sytuacjach, co do których zgodzili się już (w oparciu o racje normatywne), że zasadne jest w nich zastosowanie określonej metody randomizacji. Przyjmijmy np., że dana grupa zgodziła się, iż będzie podejmować decyzje metodą „losowo-dyktatorską”, tzn. taką, w której dla konkretnego problemu podziału będzie wybierany losowo jeden z członków grupy i to jego indywidualna decyzja stanie się automatycznie decyzją zbiorową. Przyjrzyjmy się dwóm równoważnym procedurom realizującym tę metodę (są one równoważne w tym sensie, że dają każdemu równą szansę ex ante decydowania o zachowaniu grupy): (1) najpierw losowo wybierany jest „dyktator”, który następnie ogłasza swoją decyzję; (2) najpierw każdy z członków grupy zapisuje na kartce swoją decyzję, potem wybierana jest losowa jedna osoba z grupy („dyktator”), która następnie odczytuje swoją decyzję. Mimo iż procedury te są równoważne, większość badanych uznała drugą z nich za bardziej sprawiedliwą, prawdopodobnie dlatego, że pozwala wszystkim uczestnikom loterii na aktywne w niej uczestnictwo (por. Eliaz

13 Literacką ilustrację jawnie irracjonalnego (bo pomijającego obecne dobre racje) stosowania metody losowej jest sędzia Pletewka z arcydzieła Rabelais Gargantua i Pantagruel rozstrzygający wszystkie sprawy sądowe wedle wyników rzutu kośćmi. 
\& Rubinstein, 2014) ${ }^{14}$. Tego rodzaju czynniki pomijam jednak w swoich rozważaniach; należą one już do obszaru psychologii, nie etyki. Należy jednak oczywiście o nich pamiętać, nadając przyjętej metodzie randomizacji określoną postać: mogą one bowiem wpłynąć na poziom jej akceptacji.

Przejdę teraz do omówienia racji normatywnych na rzecz RE. Można je podzielić na dwie grupy: na takie, które dostarczają uzasadnienia sprawiedliwościowego, i na takie, które dostarczają uzasadnienia nie-sprawiedliwościowego/utylitarystycznego (w szerokim sensie, obejmującym każde uzasadnianie odwołujące się do bilansu różnego rodzaju zysków i kosztów). Różnica między nimi jest istotna. Pierwsze albo nie zakładają istnienia sprawiedliwego wyniku (uprzedniego wobec zastosowania RE) dla danej sytuacji dystrybucyjnej, albo zakładają istnienie sprawiedliwego wyniku polegającego na równym podziale dobra/ciężaru, którego jednak - z uwagi na niepodzielność dobra/ciężaru - nie da się zrealizować. RE jest zatem albo odpowiedzią na brak kryterium sprawiedliwości, ewentualnie niewspółmierność kryteriów (w których to dwóch przypadkach dawanie wyrazu zasadzie egalitarnej przez RE polega na jej wprowadzaniu i następnie realizowaniu), albo środkiem służącym wyłącznie realizowaniu egalitarnego kryterium sprawiedliwości. Natomiast drugie zakładają, że istnieje sprawiedliwy wynik dystrybucji, który jest nieegalitarny ${ }^{15}$, ale różnego rodzaju koszty (ekonomiczne, psychologiczne czy społeczne) związane z jego znalezieniem lub realizacją są wyższe niż wynikające stąd korzyści. Podkreślę raz jeszcze, że w kontekście moich rozważań termin „utylitarystyczne” ma luźne czy może raczej szczególne znaczenie: odnosi się do racji, które: (a) uzasadniają zastosowanie metod losowych z uwagi na to, że ich niezastosowanie skutkowałoby negatywnym bilansem różnego rodzaju kosztów i korzyści, oraz (b) zakładają, że istnieje sprawiedliwy wynik (tzn. wyznaczony przez relewantne dla danej sytuacji kryterium sprawiedliwości, np. potrzeby, wysiłku, pracy, zasługi itd.), który jest nieegalitarny. Warto zauważyć, że utylitaryzm ściśle rozumiany może być ujmowany jako oferujący sui generis kryterium dla klasycznego ujęcia sprawiedliwości (lub, o czym mowa poniżej, eksplikację tradycyjnego kryterium potrzeby), mianowicie: kryterium nakazujące wybór alokacji maksymalizujących funkcję dobrobytu społecznego (społecznej użyteczności). Oznacza to, że randomizacja uzasadniona utylitarystycznie $w$ sensie ścisłym, tzn. z uwagi na to, że

14 Dokładniej: $52 \%$ badanych uznało drugą procedurę za bardziej sprawiedliwą, 5\% - pierwszą, natomiast $43 \%$ badanych uznało obie za równie sprawiedliwe. Warto dodać, że także w Polsce prowadzone były (przez Grzegorza Lissowskiego) empiryczne badania nad probabilistycznymi procedurami dystrybucji (procedurami Szaniawskiego); por. Lissowski, 1994.

15 Odnośnie do sytuacji, w której stosuje się RE z uwagi na to, że racje utylitarystyczne wskazują na wysokie koszty znalezienia sprawiedliwego wyniku, należy zauważyć, że sprawiedliwy wynik jest z wysokim prawdopodobieństwem nieegalitarny, a nie po prostu nieegalitarny, nie wiemy bowiem ostatecznie, jaki on jest (liczba możliwych wyników nieegalitarnych jest jednak oczywiście nieporównanie większa niż wyników egalitarnych, albowiem prawdopodobieństwo, że kandydaci spełniają dane kryterium w różnym stopniu, jest większe niż prawdopodobieństwo, że spełniają je w stopniu równym). 
istnieja co najmniej dwaj kandydaci do niepodzielnego dobra, którym przyznanie tego dobra generuje równie wysokq ( $i$ wyższq niz pozostałych kandydatów) społecznq użyteczność, byłaby w istocie randomizacja uzasadnionq sprawiedliwościowo (chodzi o omówioną niżej R3). W dalszej części, pisząc o racjach utylitarystycznych jako odrębnych od sprawiedliwościowych, mam więc na myśli takie racje, które uzasadniają stosowanie RE, mimo iż wynik sprawiedliwy jest nieegalitarny (przy czym wynik ten może być wyznaczony przez utylitarystyczne - w sensie ścisłym - kryterium dystrybucji, jeśli takie kryterium zostało uznane przez osoby dokonujące dystrybucji za właściwe).

Dla celu, jaki zamierzam zrealizować w tej części pracy - przedstawienia pewnej polemicznej wobec Johna Broome'a propozycji normatywnej - wystarczające będzie szczegółowe omówienie wyłącznie racji sprawiedliwościowych. Będę bronił tezy, że istnieją trzy racje tego rodzaju (oznaczam je jako R1, R2, R3) ${ }^{16}$; wystąpienie którejkolwiek z nich sprawia, że RE jest nie tylko dopuszczalna, ale i wymagalna.

(R1: niedookreślenie sytuacji w sensie braku kryteriów): Dla danej sytuacji dystrybucyjnej nie istnieja zadne kryteria sprawiedliwości.

Racja ta wydaje się mieć jednak charakter raczej hipotetyczny, trudno bowiem wyobrazić sobie sytuację dystrybucji, do której nie miałoby zastosowania żadne kryterium sprawiedliwości. Sytuacje, o których można sądzić, że spełniają ten warunek, przy bliższej analizie okazują się zwykle sytuacjami, o których mówi R2, mianowicie takimi, dla których istnieje wiele różnych cząstkowych kryteriów sprawiedliwości trudnych do zagregowania w jedno całościowe kryterium. Można byłoby jednak argumentować, że R1 dotyczy do pewnego stopnia dystrybucji tych stanowisk i pozycji społecznych, do pełnienia których nie są wymagane żadne szczególne kompetencje (poza ewentualnie zdrowym rozsądkiem), a które wiążą się z prestiżem lub wysokim wynagrodzeniem i dlatego są pożądane. Wydaje się, że uzasadnienie wyboru przez losowanie (części) urzędników i sędziów w starożytnych Atenach (praktyka nazywana później sortitio) opierało się właśnie na przekonaniu o braku istnienia adekwatnych kryteriów dystrybucji stanowisk publicznych ${ }^{17}$.

(R2: niedookreślenie sytuacji w sensie niewspótmierności kryteriów): Dla danej sytuacji dystrybucyjnej istnieje wiele kryteriów sprawiedliwości, które prowadza do różnych

16 Moja propozycja jest już w istocie zawarta w powyższym - ogólnym - opisie racji sprawiedliwościowych.

17 Gdyby jednak przyjąć, że obywatele starożytnych Aten uważali, że istnieją szczególne kompetencje, jakich można oczekiwać od urzędnika czy sędziego (a więc że dla dystrybucji władzy istnieje relewantne kryterium sprawiedliwości), mogłoby to oznaczać, że wybierając losowo urzędników czy sędziów, kierowali się racjami utylitarystycznymi, zwracając np. uwagę na pozytywne skutki tej metody (takie jak zmniejszenie ryzyka pojawienia się tyranii, edukacja obywatelska, zapobieżenie tworzeniu się elit politycznych, przeciwdziałanie korupcji politycznej). Nie można też wykluczyć, że uzasadnienie tej metody miało pierwotnie charakter religijny, metafizyczny (losowanie jako metoda ujawnienia woli bóstw); jeśli jednak uzasadnienie sortitio miało pierwotnie taki charakter, to wydaje się, że z biegiem czasu ustąpiło uzasadnieniom świeckim (por. Elster, 1987, s. 158; Goodwin, 2005, s. 53; De Coulanges, 1882, s. 143). Obszerną analizę sortitio - jej wad i zalet można znaleźć np. w Dowlen, 2008, i Fishkin, 1999. 
wyników (tzn. „rankingi” kandydatów układanych według tych kryteriów sq odmienne), i z uwagi na niewspótmierność tych kryteriów nie jest możliwe ich zagregowanie do postaci jednego złożonego kryterium sprawiedliwości.

Racja ta obejmuje w istocie dwa elementy: „abstrakcyjny”, dotyczący cech samej sytuacji dystrybucyjnej, w której mają zastosowanie różne, niewspółmierne kryteria sprawiedliwości, oraz „konkretny”, związany z tym, że w danym przypadku tego rodzaju sytuacji kandydaci wypadają odmiennie według różnych kryteriów sprawiedliwości (gdyby rankingi tworzone według owych niewspółmiernych kryteriów były identyczne, randomizacja byłaby oczywiście bezzasadna). Z tego rodzaju sytuacjami mamy do czynienia stosunkowo często. Pojawiają się zawsze wtedy, gdy musimy dokonać w istocie „całościowej” oceny danych kandydatów. Rozważmy, przykładowo, problem dystrybucji nerek między osoby zakwalifikowane do transplantacji. Może się wydawać, że dystrybucja nie powinna tutaj rodzić poważniejszych problemów, ponieważ jedynym rozsądnym kryterium sprawiedliwości jest kryterium „potrzeby". Przy bliższej analizie okazuje się jednak, że kwestia jest bardziej skomplikowana. Nie dość, że łatwo wyobrazić sobie inne kryteria (np. czasowe - pierwszeństwa znalezienia się na liście osób zakwalifikowanych do transplantacji, „użyteczności”, jaką dana osoba przedstawia względem społeczeństwa, czy oczekiwanej długości życia), które mogą być sprzeczne z kryterium potrzeby, to również samo kryterium potrzeby dopuszcza co najmniej dwie odmienne interpretacje mogące prowadzić do sprzecznych wyników (por. Elster, 1987, s. 130-131). Według pierwszej, najbardziej potrzebującymi są ci, którzy z uzyskanego dobra odniosą największą korzyść (tzn. ich marginalny przyrost dobrostanu będzie największy), zaś według drugiej - ci, którzy są na najniższym poziomie dobrostanu. Interpretacje te nie muszą prowadzić do identycznych rezultatów, tzn. wskazywać tę samą osobę. Jeśli np. osoba będąca na niższym poziomie dobrostanu mniej skutecznie „przekształca” dane dobro w kolejne jednostki dobrostanu, interpretacje te rodzą trudny dylemat: Czy pomóc osobie bardziej cierpiącej, czy tej, która silniej odczuje zmianę swojej sytuacji? Jeśli weźmie się dodatkowo pod uwagę inne kryteria oprócz kryterium potrzeby, trudno będzie bona fide twierdzić, że dla tego rodzaju sytuacji istnieje jedno sprawiedliwe rozwiązanie, tyle że niełatwe do znalezienia. Zauważmy jeszcze, nawiązując do wcześniejszych rozważań na temat różnic między podejściami filozoficznym i teorii wyboru społecznego do zagadnień podziału dóbr/ciężarów, że obie eksplikacje pojęcia potrzeby do pewnego stopnia przypominają kryterium dystrybucji przyjmowane w ramach teorii wyboru społecznego, tj. do kryterium preferencji kandydatów, a więc użyteczności, jakie przypisują oni dzielonym dobrom. Przykład dystrybucji nerek pokazuje jednak wyraźnie, że samo to kryterium, potraktowane ściśle, jest w tym przypadku nieprzydatne w rozwiązaniu problemu dystrybucji, i to z dwóch powodów. Po pierwsze, wszystkim uczestnikom dystrybucji zależy na uzyskaniu narządu do przeszcze- 
$\mathrm{pu}$ - nie ma tu więc różnorodnych dóbr, dla których uczestnicy dystrybucji mogliby tworzyć ranking. Po drugie, gdyby chcieć doszukać się w obu interpretacjach pojęcia potrzeby jakiegoś podobieństwa do kryterium preferencji, okazałoby się, że przybiera ono tutaj niejako zobiektywizowaną postać. W interpretacjach tych chodzi bowiem o obiektywną (zewnętrzną) ocenę przyrostu dobrostanu każdego z kandydatów, który by nastąpił, gdyby dany kandydat poddał się przeszczepowi, lub o obiektywną ocenę jego „obecnego” (tj. przed dokonaniem przeszczepu) poziomu; subiektywna ocena samego kandydata jest z pewnością pomocna w sformułowaniu tej oceny, ale nie wyczerpuje definicyjnie żadnego z obu pojęć potrzeby.

(R3: niedookreślenie sytuacji w sensie indyferencji - równego spetniania kryteriów): Kandydaci do uzyskania danego dobra/poniesienia ciężaru w równym stopniu spetniaja określone kryterium sprawiedliwości.

Bardziej liberalna wersja tej racji (broniona np. przez Johna Broome'a), uwzględniająca możliwość błędu przy ocenie stopnia spełniania kryterium sprawiedliwości i/lub nieistotność drobnych różnic w spełnianiu tego kryterium, ma postać następującą: kandydaci do uzyskania danego dobra/poniesienia ciężaru spełniają określone kryterium sprawiedliwości w równym lub niemal równym stopniu ${ }^{18}$.

Można się zastanawiać, czy nie należałoby wyróżnić jeszcze jednej racji sprawiedliwościowej (R4) za RE, mianowicie sytuacji, w której wiadomo, że tylko jeden z kandydatów spełnia kryterium sprawiedliwości, ale nie wiadomo, i nie da się tego stwierdzić, który z nich je spetnia. Nie jest jednak jasne, czy taka racja może być zasadnie nazwana „sprawiedliwościową". Z jednej bowiem strony sprawiedliwa dystrybucja, do której odnosi się R4, jest, z założenia, nieegalitarna. RE jest więc tutaj sprzeczna ze sprawiedliwą dystrybucją (tyle że niepoznawalna). Z drugiej jednak strony R4 nie spełnia także definicji racji utylitarystycznej, tj. takiej, która dopuszcza RE, mimo iż (znana lub przynajmniej poznawalna) sprawiedliwa dystrybucja jest nieegalitarna (sprawiedliwa dystrybucja, do której odnosi się R4, jest wprawdzie nieegalitarna, ale nie da się stwierdzić, o jaką konkretnie nieegalitarną dystrybucję chodzi). Jak się więc wydaje, R4 nie byłaby tedy ani racją sprawiedliwościową, ani utylitarystyczną. Niejasny jest jednak nie tylko charakter tej racji. Wątpliwości budzi także jej siła normatywna. O ile bowiem wystąpienie R1, R2 lub R3 sprawia, że RE jest dopuszczalna i wymagalna, o tyle nie jest nawet jasne, czy wystąpienie R4 uzasadnia dopuszczalność RE, nie wspominając już o jej wymagalności ${ }^{19}$.

18 Za przykład randomizacji uzasadnionej tą racją można uznać np. losowy pobór do wojska (por. Feinberg, 1971) czy losowy wybór członków ławy przysięgłych, choć można oczywiście wskazywać także odmienne racje za zastosowaniem w tych przypadkach losowej metody dystrybucji.

19 Wydaje się, że R4 mogła być traktowana jako uzasadnienie procedury „dziesiątkowania” stosowanej w wielu armiach (np. rzymskiej). Choć, jeśli przyjmiemy, że winni (np. tchórzostwa) byli wszyscy żołnierze, uzasadnienie „dziesiątkowania” miałoby inny charakter - utylitarystyczny, jasno opisany przez Machiavellego: „Najstraszniejszą ze wszystkich była kara dziesiątkowania armii, polegająca na tym, że drogą losowania 
Jeśli chodzi o relatywną wagę obu typów racji - sprawiedliwościowych i utylitarystycznych - za zastosowaniem RE, wydaje się, że pierwsze są silniejsze niż drugie. Wystąpienie racji sprawiedliwościowych sprawia, jak wspomniano, że RE jest dopuszczalna i wymagalna; dla sytuacji, które opisują te racje, trudno bowiem znaleźć jakąś równie przekonującą metodę dystrybucji. Inaczej jest w przypadku racji utylitarystycznych. Mogą one uzasadniać RE tylko w wyjątkowych przypadkach, mianowicie wtedy, gdy wskazane przez te racje koszty podjęcia i/lub realizacji sprawiedliwej decyzji są szczególnie wysokie. Randomizacja uzasadniona utylitarystycznie może być wprawdzie słuszną/właściwą/wskazaną/uzasadnioną metodą podejmowania decyzji dystrybucyjnej, nie jest jednak, ex definitione, metodą sprawiedliwą, jest bowiem stosowana mimo istnienia sprawiedliwego (nieegalitarnego) rozstrzygnięcia ${ }^{20}$. Ten prosty fakt - iż racje utylitarystyczne nakazują stosowanie RE wtedy, gdy wiadomo, że sprawiedliwy wynik jest nieegalitarny - sprawia właśnie, że racje utylitarystyczne powinny być uwzględniane tylko wyjątkowo.

Na zakończenie tego punktu powrócę jeszcze do pojęcia racji sprawiedliwościowych. Pojęcie to rozumiem szeroko: jako obejmujące R1, R2 i R3 (kwestię statusu R4 pozostawiam nierozstrzygnięta). Nie jest to pogląd powszechnie przyjmowany. Przykładowo, odmienne stanowisko odnośnie do tych racji przyjmuje John Broome, który pisze, że „jeśli losowy przydział dobra ma być usprawiedliwiony, należy pozy-

skazywano na śmierć co dziesiątego żołnierza. Trudno ukarać rzeszę ludzi w sposób bardziej srogi; kiedy zawiniło wielu i nie ma głównych winowajców, nie sposób skazać wszystkich, gdyż nie pozwala na to ich liczba. Gdyby część ukarać, a części wybaczyć, wyrządziłoby się krzywdę ukaranym, a pozostałych zachęciło do nowych wykroczeń. Kiedy jednak wszyscy zasługują na śmierć, a umiera tylko co dziesiąty, wyznaczony drogą losowania, skarży się on jedynie na brak szczęścia, pozostali natomiast wiedzą, że im to samo może się przydarzyć, i ze strachu więcej nie błądzą" (Machiavelli, 1993, s. 388). Za pomocą R4 można byłoby też uzasadniać np. przepisy karne z XVII- i XVIII-wieczej Szwecji i Finlandii, które nakazywały losowo wybierać skazanego w przypadku zabójstw, w których brało udział kilku sprawców, ale nie było wiadomo, który z nich zadał śmiertelny cios (oskarżeni ciągnęli losy; ten, kto trafił na pechowy, był skazywany na śmierć; por. Elster, 1987, s. 157). Elster trafnie zauważa, że przynajmniej częściowo przepisy te mogły być także motywowane prawem talionu: życie powinno być oddane za życie, ale za jedno życie tylko jedno.

20 Niezgodność między RE uzasadnioną utylitarystycznie i sprawiedliwością polega zazwyczaj właśnie na tym, że wynik randomizacji jest niezgodny z wynikiem wskazanym przez kryterium sprawiedliwości. Warto jednak dodać, że może polegać także na samym zaniechaniu dokonania dystrybucji. Tak jest np. w przypadku pewnej (niezrealizowanej w praktyce) propozycji, motywowanej względami utylitarystycznymi, zastosowania losowej metody przy rozstrzyganiu sporów w sądach cywilnych (por. Rosenberg \& Shavell, 2005). Nieco upraszczając, można powiedzieć, że wedle standardowej reguły stosowanej w sądach, jeśli powód żąda od sprawcy deliktu odszkodowania w określonej wysokości $x$, sędzia rozpatruje sprawę i przyznaje odszkodowanie w wysokości $x$, jeśli powód wykaże zasadność swojego roszczenia. Zgodnie natomiast z ową losową procedurą, ilekroć powód wnosiłby roszczenie, sędzia rzucałby monetą i oddalał roszczenie, jeśliby wypadła „reszka”, lub przyznawałby odszkodowanie w podwójnej wysokości $2 x$, gdyby wypadł „orzeł” (a powód wykazałby zasadność swojego roszczenia). Wartość oczekiwana odszkodowania jest identyczna dla każdej z metod, jednak metoda losowa ograniczałaby liczbę procesów o 50\% i tym samym prowadziłaby do zaoszczędzenia kosztów administracyjnych (przez redukcję prawdopodobieństwa wytoczenia zasadnego procesu i zrekompensowanie go zwiększonym odszkodowaniem). Metoda ta jest pomysłowa, ale raczej nie może liczyć na społeczną aprobatę - jest zbyt odległa od dość powszechnej intuicji etycznej, domagającej się sprawiedliwego rozstrzygnięcia w każdej konkretnej sprawie. Na temat innych zastosowań randomizacji w prawie por. np. Duxbury, 1999. 
tywnie wykazać, że roszczenia kandydatów do dobra są co najmniej w przybliżeniu równe" (Broome, 1984. s. 51); odrzuca więc racje R1 i R2, uznając tylko R3 (którą jednak, jak wspomniałem, rozumie liberalnie). Dla sytuacji, których dotyczy R2, Broome sugeruje przeprowadzenie skrupulatnej analizy zmierzającej do stworzenia, mimo wielości kryteriów, rankingu kandydatów ${ }^{21}$. Rozwiązanie Broome'a nie wydaje się jednak przekonujące. W przypadku kryteriów, które są niewspółmierne, ich „ważenie" (i następnie tworzenie rankingu kandydatów) będzie zawsze naznaczone arbitralnością 22; rozwiązanie Broome’a stwarza więc ryzyko przywołania „złych racji”. Ponadto rygoryzm Broome'a w kwestii racji sprawiedliwościowych opiera się na założeniu, iż w każdym innym przypadku niż ten, w którym można stwierdzić, iż roszczenia kandydatów są w przybliżeniu równe, a więc w przypadkach R1 i R2, mielibyśmy $\mathrm{w}$ istocie do czynienia z zastosowaniem zasady racji niedostatecznej (principle of insufficient reason). Broome przypomina, że jest ona problematyczna w kontekście teorii prawdopodobieństwa (prowadzi do różnych wyników zależnie od tego, w jakim sposób dokonamy podziału przestrzeni zdarzeń), i twierdzi, że per analogiam - jest ona także problematyczna w kontekście przypisywania „wag” roszczeniom kandydatów: odpowiednikiem arbitralności podziału zdarzeń z przestrzeni probabilistycznej miałaby być tutaj arbitralność „wag” roszczeń wynikająca stąd, iż można przyjąć różne kryteria sprawiedliwości determinujące owe wagi (np. osiągnięcia wieku 65 lat, przeżycia kolejnych czterech lat czy jakości życia, w przypadku dystrybucji rzadkiego dobra, jakim jest hemodializa ${ }^{23}$ ). Analogia wydaje mi się jednak pozorna. Sedno problemu tkwi bowiem właśnie w tym, że przy dokonywaniu dystrybucji mamy do czynienia albo z brakiem tego rodzaju kryteriów (R1), albo z ich wielościa i niewspótmiernościa (R2), sprawiającymi, że, z punktu widzenia praktycznego, następuje niejako ich wzajemne „zniesienie”/,zneutralizowanie”, tzn. podmiot dokonujący dystrybucji nie ma żadnych racji, aby zastosować określone z nich (nie ma żadnych podstaw do budowania ich "rankingu”). Z tego względu, wbrew tezie Broome'a, zasada racji niedostatecznej ma w kontekstach, do których odnoszą się R1 i R2, inny charakter niż w kontekście probabilistycznym: w tym ostatnim może prowadzić do błędnych askrypcji wartości prawdopodobieństw (ponieważ zdarzenia, którym przypisuje owe wartości, posiadają już określone war-

21 Ograniczam się do analizy poglądów Broome'a wyrażonych w artykule Selecting People Randomly z 1984 roku; w późniejszym artykule Fairness (1990) Broome wydaje się dopuszczać RE w sytuacji, którą opisałem jako R2 (a którą autor określa jako „being tied within the limtis of comparability” (Broome, 1990, s. 100); jego stanowisko nie jest jednak całkiem jasne, dodaje bowiem, że "argument from incomparability provides no reason why a fixed rule should be worse than lottery" (ibidem, s. 101).

22 Mniejszą lub większą, w zależności od tego, jak rzetelna i otwarta była dyskusja, która doprowadziła do wypracowania ewentualnego meta-kryterium (uwagę tę zawdzięczam anonimowemu recenzentowi, z którym jednak różnię się o tyle, że uważam, iż, przy założeniu niewspółmierności kryteriów, całkowite wyeliminowanie arbitralności nie jest możliwe).

23 Przykład Broome'a. 
tości, tyle że nieznane ${ }^{24}$ ), i narażona jest na zarzut arbitralności (z uwagi na różne sposoby podziału przestrzeni zdarzeń); natomiast w kontekstach dystrybucji dóbr, do których odnoszą się R1 i R2, błąd jest wykluczony (ponieważ roszczenia nie mają żadnych wag uprzednich wobec zastosowania tej zasady), podobnie jak arbitralność (wagi są w naturalny sposób przydzielane samym kandydatom).

\section{RACJE ZA ZASTOSOWANIEM RANDOMIZACJI PROPORCJONALNEJ}

W sytuacji dystrybucyjnej, w której można stwierdzić, w jakim stopniu kandydaci spełniają określone kryterium sprawiedliwości i w której stopnie te są różne (przynajmniej dla dwóch kandydatów), randomizacja polega na dystrybucji szans otrzymania niepodzielnego dobra/ciężaru. Jak wspomniano w punkcie 2, ogólną racją za taką procedurą (jej sensem) jest to, że respektuje ona, przez uwzględnienie stopnia spełniania kryterium przez każdą osobę, zasadę proporcjonalności, która jest realizowana właśnie za pomocą dystrybucji szans. Zgodnie z tą racją, danie każdej osobie szansy uzyskania dobra/poniesienia ciężaru, która jest proporcjonalna do spełnienia przez nią kryterium sprawiedliwości, jest bardziej sprawiedliwe niż przyznanie dobra/ciężaru osobie, która spełnia dane kryterium w najwyższym stopniu. Innymi słowy, RP jest sprawiedliwa ex ante, tj. z uwagi na procedurę dającą każdemu szansę otrzymania dobra/ciężaru proporcjonalną do stopnia spełniania przez nią kryterium sprawiedliwości; niezastosowanie randomizacji oznaczałoby pominięcie faktu, że osoby spełniające to kryterium w mniejszym stopniu jednak je spełniają. RP ma jednak istotną wadę: może być ona niesprawiedliwa ex post (tj. z uwagi na wynik), np. z dwóch kandydatów, z których jeden spełnia kryterium potrzeby w $20 \%$, a drugi - w $80 \%$, dobro może otrzymać ten pierwszy. Problem możliwego konfliktu między sprawiedliwością ex ante i ex post okazuje się poważny, nawet jeśli uwzględni się fakt, że poziom możliwej niesprawiedliwości ex post jest wprost proporcjonalny do różnic w roszczeniach kandydatów, co oznacza, że im niesprawiedliwość ex post jest bardziej rażąca, tym ryzyko jej wystąpienia jest mniejsze. Nie jest łatwo stwierdzić, czy należy dać pierwszeństwo sprawiedliwości ex ante, i tym samym dopuścić RP, czy sprawiedliwości ex post, i tym samym wykluczyć RP. Gdyby można było twierdzić, że skupienie się na sprawiedliwości ex post i nieumiejętność przyjęcia perspektywy ex ante w przypadku wystąpienia niesprawiedliwego wyniku jest błędem poznawczym czy też jakimś innym przejawem nieracjonalności (np. analogicznym do hindsight bias), stanowiłoby to silny argument na rzecz RP. Trud-

24 Przykładowo, jeśli mamy podać liczbę kul w określonych kolorach znajdujących się w danej urnie, możemy się pomylić, stosując zasadę indyferencji, ponieważ w urnie znajdują się już kule w określonych kolorach, tyle że nie wiemy, jaki ich jest „rozkład” (tzn. ile jest kul w danym kolorze). 
no jednak uznać, że mamy tutaj do czynienia z jakimś błędem poznawczym - obie perspektywy wydają się równie racjonalne, o czym świadczy choćby sam fakt, że pojęcia sprawiedliwości ex ante (nazywanej niekiedy „sprawiedliwością procedury/ wyboru”) i ex post (nazywanej niekiedy „sprawiedliwością wyniku”) zakorzeniły się w filozoficznym dyskursie jako w pełni uprawnione (por. np. Lang, 2005; Broome, 1990). W związku z tym wydaje się, że RP jest dopuszczalna (nie przesądzam, czy także wymagalna) tylko w takich kontekstach, w których ów potencjalny konflikt między sprawiedliwością ex ante i ex post zostanie albo złagodzony, albo wyeliminowany. Wydaje się, iż można wyróżnić dwa tego rodzaju konteksty.

(Kontekst 1) Jeśli dana decyzja dystrybucyjna jest jednorazowa (tzn. przydział dóbr czy ciężarów jest ostateczny), a więc randomizacja może być stosowana tylko jeden raz, zastosowanie RP jest wykluczone, chyba że różnice między kandydatami w stopniu spetniania przez nich kryterium sprawiedliwości wtaściwego dla danego podziału nie sa duże ${ }^{25}$.

Trudno dokładnie wskazać wielkość, jakiej różnice nie powinny przekraczać, ale można przyjąć, że chodzi o rozbieżności nieduże ${ }^{26}$. Rzecz jasna, wymóg niewielkich różnic w roszczeniach kandydatów, mający eliminować poważna niesprawiedliwość ex post, ma również swoją negatywną stronę: o ile bowiem poziom potencjalnej niesprawiedliwości ex post i różnice w roszczeniach są do siebie wprost proporcjonalne, o tyle częstotliwość potencjalnej sprawiedliwości ex post i różnice w roszczeniach są do siebie odwrotnie proporcjonalne, co będzie skutkowało tym, że w omawianym kontekście niesprawiedliwość ex post będzie się pojawiała stosunkowo często (tyle że nie będzie miała charakteru rażącego). Należy zwrócić uwagę także na to, iż ów niski poziom różnic w spełnianiu kryterium sprawiedliwości nie stanowi jeszcze wystarczającego warunku zastosowania RP. Dopuszczalność RP będzie także zależała od charakteru dzielonego dobra. Byłoby np. absurdem wyłanianie zwycięzcy biegu maratońskiego za pomocą loterii z wagami proporcjonalnymi do uzyskanego czasu. Trudno podać jakąś ogólniejszą regułę, która rozstrzygałaby, jakiego rodzaju dobra niepodzielne mogą być dystrybuowane metodą RP. W znanej mi literaturze nie znalazłem żadnych pogłębionych rozważań na ten temat, co może świadczyć od tym, że niełatwo wskazać tego rodzaju ogólną regułę, która uzasadniałaby, dlaczego np.

25 Istnieje podobieństwo między tym warunkiem a propozycją Johna Broome’a, który twierdzi, że decyzja o zastosowaniu loterii proporcjonalnej powinna zależeć od ważenia różnych typów sprawiedliwości/niesprawiedliwości: „należy porównać prawdopodobieństwo wystąpienia mniej sprawiedliwego (less fair) wyniku z wkładem, jaki w realizację sprawiedliwości ma sama loteria (Broome, 1990, s. 99).

$26 \mathrm{~W}$ jednej z wcześniejszych wersji tego artykułu napisałem: „nie większe niż 20\%”. Anonimowy recenzent słusznie jednak zapytał: „Skąd ta arbitralna decyzja? Czy 20\% próg rozbieżności jest wynikiem konsensusu naukowego opartego na przeprowadzonych analizach, tudzież badaniach?”. Ograniczam się więc do stwierdzenia, że powinny być one „nieduże”, a rozstrzygnięcie, co znaczy „nieduże”, należy pozostawić w gestii phronesis podmiotu dokonującego konkretnej decyzji dystrybucyjnej; ów próg może być bowiem różny dla poszczególnych sytuacji dystrybucyjnych (w niektórych przypadkach niesprawiedliwość ex post może być szczególnie bolesna, dlatego próg rozbieżności powinien być w nich niższy; wydaje się, że jest tak np. w przypadku dystrybucji ciężarów). 
wyłanianie zwycięzcy biegu maratońskiego za pomocą RP jawi się na pierwszy rzut oka jako absurdalne, a np. przydzielanie narządów do przeszczepu - już nie ${ }^{27}$.

(Kontekst 2) Jeśli dana decyzja dystrybucyjna jest powtarzana (a więc przydział dóbr nie jest ostateczny), można zastosować RP niezależnie od stopnia spetniania przez kandydatów relewantnego kryterium sprawiedliwości.

Przykładowo, jeśli różni kandydaci na jedno miejsce pracy spełniają określone kryterium wyznaczone przez pracodawcę w różnym stopniu, nie stosuje się randomizacji (tj. nie dystrybuuje się szans), lecz przyznaje stanowisko tej osobie, które spełnia to kryterium w największym stopniu. Gdyby jednak miejsce pracy było przydzielane wielokrotnie (czasowo) tej samej grupie kandydatów, zastosowanie RP byłoby, jak się wydaje, dopuszczalne, nawet jeśli różnice między kandydatami w spełnianiu przez nich kryterium byłyby duże.

Powtórzmy: proponowane wyżej „dwutorowe” rozwiązanie problemu dopuszczalności RP pozwala uchylić podstawowy, jak się wydaje, zarzut wobec RP, tj. zarzut możliwości wystąpienia jawnie niesprawiedliwego wyniku dystrybucji. W pierwszym kontekście niesprawiedliwy wynik może się pojawić, ale nie będzie on bardzo czy rażąco niesprawiedliwy z uwagi na niewielką różnicę w roszczeniach kandydatów uczestniczących w dystrybucji. W drugim kontekście właśnie z racji tego, że dystrybucja ta nie jest ostateczna, lecz stanowi jeden z elementów ciągu różnych dystrybucji, jej ewentualna niesprawiedliwość ex post zostaje złagodzona, zminimalizowana lub nawet - gdyby stworzyło się odpowiednio długi ciąg tego rodzaju dystrybucji usunięta (w tym przypadku czas posiadania dobra przez poszczególnych kandydatów byłby proporcjonalny do siły ich roszczeń).

Nie ulega jednak wątpliwości, że przedstawione wyżej konteksty dopuszczalnego zastosowania RP poważnie ograniczają jej praktyczne znaczenie. Jeśli chodzi o kontekst pierwszy, pojawia się w nim dość istotny problem: jeśli bowiem różnice w roszczeniach kandydatów są nieduże, można przypuszczać, iż rodzić się w nich będą spory o to, czy różnice te w ogóle występują (przypuszczenie to opiera się na hipotetycznej przesłance, że intensywność sporów o relatywną wartość roszczeń będzie odwrotnie skorelowana z rzeczywistymi różnicami w sile tych roszczeń). Można się zastanawiać, czy w tym kontekście, ze względów utylitarystycznych, nie należałoby zastosować RE (zauważmy zresztą, że gdyby różnice między roszczeniami kandydatów były bardzo małe, jedna z racji sprawiedliwościowych - R3 - nakazywałyby stosowanie RE). Jeśli chodzi o kontekst drugi (powtarzalność), będzie on występował

27 Pewną sugestię rozwiązania tego problemu znajduję w uwadze anonimowego recenzenta, iż „losowa dystrybucja miejsc w zawodach sportowych zmienia całą sytuację i nie mamy już do czynienia z zawodami sportowymi". Można by ją rozwinąc do takiej formuły: randomizacja jest wykluczona w kontekście takich aktywności związanych z przyznawaniem dóbr/ciężarów, w przypadku których nielosowość należy do ich elementów konstytutywnych. Randomizacja unicestwiałaby więc, niejako z definicji, same te aktywności. 
bardzo rzadko, albowiem decyzje dystrybucyjne są zwykle jednorazowe, np. przydział narządów do przeszczepu czy przyjmowanie uczniów do szkół. Jeśli chodzi o ten ostatni przykład, należy jednak dodać, że praktyka jest dość często odmienna od przedstawionej tu propozycji normatywnej, tzn. w takiej sytuacji RP jest nierzadko stosowana: kandydaci oceniani są w systemie punktowym, na podstawie różnych kryteriów, a prawdopodobieństwo przyjęcia jest proporcjonalne do uzyskanej liczby punktów. Racje za przyjęciem RP w tego rodzaju sytuacji dystrybucyjnej są jednak nieprzejrzyste. Można rekonstruować je różnorako. Zdaniem Elstera system taki „przypuszczalnie ma służyć osiągnięciu kompromisu między indywidualnymi potrzebami i społeczną użytecznością, między sprawiedliwością i efektywnością" (Elster, 1987, s. 116). Można także twierdzić, że tego rodzaju system przyjmowania kandydatów jest wyrazem sceptycyzmu jego twórców co do adekwatności oceny kandydatów na podstawie różnych kryteriów; w tej interpretacji RP byłaby więc jakąś próbą kompromisowego rozwiązania problemu niewspółmierności kryteriów (o którym pisałem wcześniej, omawiając R2 za przyjęciem RE), odrzucającego z jednej strony możliwość stworzenia w pełni wiarygodnej hierarchii kandydatów, a z drugiej odrzucającego tezę o niemożliwości stworzenia jakiejkolwiek hierarchii. Nie jest wykluczone, że aby właściwie zrekonstruować racje stojące za tym systemem, należałoby uwzględnić racje z poziomu „makro-sprawiedliwości”; system ten należałoby wówczas ujmować jako służący w pewnym przynajmniej stopniu rekompensowaniu naturalnych czy społecznych nierówności między kandydatami.

\section{RP W WERSJI „ROZWARSTWIONEJ"}

W powyższych rozważaniach wyróżniłem dwa konteksty, w których stosowanie RP jest dopuszczalne. Można byłoby jednak próbować bronić tezy, że istnieje pewien szczególny rodzaj RP, mianowicie loteria rozwarstwiona (stratified lottery), która może być stosowana także w przypadku dystrybucji jednorazowej przy dużej różnicy roszczeń między stronami. Aby móc ocenić tę tezę, przybliżmy najpierw samo pojęcie loterii rozwarstwionej. Stanowi ona swego rodzaju rozwiązanie pośrednie między przyznaniem dóbr osobom spełniającym dane kryterium sprawiedliwości w najwyższym stopniu i zastosowaniem losowej metody polegającej na dystrybucji szans zgodnie ze stopniem spełniania owego kryterium. Jon Elster (1987, s. 172) ilustruje jej działanie następującym przykładem. Załóżmy, że istnieje 10 nerek do rozdzielenia między 20 pacjentów oczekujących na przeszczep. Jako kryterium dystrybucji przyjmujemy oczekiwaną długość życia po dokonaniu przeszczepu i zakładamy, że 10 osób z owych 20 ma oczekiwaną długość życia 5 lat, a pozostałe 10 osób - 20 lat. „Loteria nierozwarstwiona" (unstratified lottery) polegałaby na zastosowaniu randomizacji w jednym 
etapie: na wyborze 10 osób za pomocą metodą dystrybucji szans, zgodnie z którą, dla każdej nerki, osoba z większą oczekiwaną długością życia ma szansę 4/50 otrzymania danej nerki, a osoba z niższą długością życia - szansę 1/50 (losowanie przebiega w 10 rundach; jeśli w danej rundzie nerkę wylosuje osoba, która wylosowała ją już w rundzie wcześniejszej, losowanie w danej rundzie jest powtarzane). W przypadku loterii rozwarstwionej dystrybucja przebiega dwuetapowo: najpierw przyznajemy proporcjonalnie każdej grupie odpowiednią liczbę nerek (dwie nerki grupie gorzej rokującej i osiem nerek grupie lepiej rokującej), a potem wybieramy losowo, stosując już randomizację egalitarną, beneficjentów z każdej grupy. Nie jest łatwo dokonać porównawczej oceny obu wariantów RP. Wymagałoby to dokładniejszych analiz, uwzględniających także inne, bardziej skomplikowane przykłady problemów dystrybucyjnych niż powyższy. Gdybym miał jednak sformułować jakąś wstępną ocenę obu wariantów RP, brzmiałaby ona następująco: wydaje się, że jednorazowa (proporcjonalna) loteria rozwarstwiona jest bardziej sprawiedliwa niż jednorazowa (proporcjonalna) loteria nierozwarstwiona - pierwsza przesądza wprawdzie, że wystąpi niesprawiedliwość ex post (gwarantuje bowiem dla grupy osób ze słabszymi roszczeniami określoną liczbę dóbr), wyklucza jednak pojawienie się rażącej niesprawiedliwości ex post (polegającej na tym, że większość lub nawet wszyscy beneficjenci będą pochodzić z grupy gorzej rokującej), której nie wyklucza z kolei loteria nierozwarstwiona (choć oczywiście nie wyklucza także wyniku sprawiedliwego ex post, tj. takiego, przy którym wszystkie dobra trafiają do osób bardziej uprawnionych; wynik ten z kolei nie jest możliwy na gruncie loterii rozwarstwionej). Jednorazowa (proporcjonalna) loteria rozwarstwiona wydaje się jednak mniej sprawiedliwa niż powtarzana (proporcjonalna) loteria nierozwarstwiona (która, przy odpowiednio dużej liczbie powtórzeń, wyklucza pojawienie się niesprawiedliwości ex post). Jeśli chodzi o powtarzaną (proporcjonalną) loterię rozwarstwioną, wydaje się, że ma ona dokładnie taki sam status moralny jak jej wariant jednorazowy (poziom niesprawiedliwości ex post będzie w loterii rozwarstwionej taki sam, niezależnie od liczby jej powtórzeń).

\section{RóŻNICE MIĘDZY RANDOMIZACJĄ EGALITARNĄ I PROPORCJONALNĄ}

W tym punkcie skupię się na omówieniu pewnych bardziej subtelnych różnic między RE i RP, na które, wedle mojej wiedzy, nie zwracano do tej pory uwagi w literaturze.

Po pierwsze, rozróżnienie na sprawiedliwość ex ante i sprawiedliwość ex post, implikujące możliwość wystąpienia konfliktu między nimi, ma wyraźny i normatywnie istotny sens wyłącznie w przypadku RP. W przypadku RE, uzasadnionej racjami 
sprawiedliwościowymi, taka rozbieżność może co prawda wystąpić, ale ma charakter dużo mniej wyraźny i normatywnie mniej istotny; rozbieżność między równością szans i nierównością wyniku nie może bowiem stanowić podstawy do skargi „przegranego”, iż wynik jest niesprawiedliwy, ponieważ nie może on powiedzieć ex post, że miał ex ante większe roszczenia do danego dobra niż zwycięzca (choć może oczywiście powiedzieć, że miał roszczenia równe - dlatego też nie można stwierdzić, że konflikt między sprawiedliwością ex ante i ex post w przypadku RE nie występuje w ogóle; ma jednak charakter normatywnie mniej istotny). Oznacza to także, że powtarzalność dystrybucji nie wzmacnia istotnie sprawiedliwościowych racji za zastosowaniem w niej RE, choć z pewnością stanowi pewną dodatkową czy raczej naddatkową rację za jej przyjęciem - a także, dodajmy, rację przeciw RE uzasadnionej utylitarystycznie (gdyż w tym ostatnim przypadku powtarzalność dystrybucji utrwalałby niejako niesprawiedliwy - egalitarny - wynik, „narzucony” przez RE przy zignorowaniu właściwego dla danej sytuacji kryterium sprawiedliwości, które, zgodnie z przyjętą definicją racji utylitarystycznych, generuje wynik nieegalitarny).

Po drugie, każda z trzech sprawiedliwościowych racji za RE ma charakter samoistny, tzn. wystarcza, bez badania dalszych okoliczności dotyczących sytuacji dystrybucyjnej, aby uzasadnić w nich zastosowanie RE. W przypadku RP nie istnieją tego rodzaju racje. Jedyną możliwą ogólną racją za zastosowaniem RP mogłoby być uznanie, że sprawiedliwość ex ante ma większą wagę niż sprawiedliwość ex post. Jest to jednak, jak argumentowałem, nieprzekonujące, ponieważ oba rodzaje sprawiedliwości mają charakter równorzędny czy równoważny. Aby można była uzasadnić zastosowanie RP, musi wystąpić jeden z dwóch szczególnych (i rzadkich) kontekstów sytuacji dystrybucyjnej, a dystrybuowane dobro/ciężar musi mieć dodatkowo taki charakter (poza tym, że jest dobrem niepodzielnym), że dopuszcza RP, przy czym, jak pisałem wcześniej, trudno wskazać jakieś ogólniejsze kryteria pozwalające wskazać, jakie dobra niepodzielne mogą być dystrybuowane za pomocą RP, a jakie nie.

Po trzecie, o ile można podawać racje utylitarystyczne za RE, o tyle samo pojęcie tego rodzaju racji nie ma sensu w odniesieniu do RP. Racje utylitarystyczne bowiem z definicji mają przemawiać za zastosowaniem randomizacji wbrew kryterium sprawiedliwości, natomiast RP ze swej natury ma dać wyraz różnicom w stopniu spełnienia kryterium sprawiedliwości.

Po czwarte, wydaje się, że RP wymaga silniejszego typu losowości niż RE uzasadniona R1 lub R2. Aby wyjaśnić tę różnicę, wprowadzę rozróżnienie na losowość silniejszą (w sensie statystycznym) i słabszą (w sensie czysto epistemicznym). Proces jest losowy w sensie statystycznym wtedy i tylko wtedy, gdy gwarantuje (w sensie częstościowym), że określone wyniki zostaną osiągnięte z określonymi prawdopodobieństwami (odpowiadającymi sile roszczeń kandydatów do dobra), i gdy żadna 
z osób, których on dotyczy, a także żadna z osób, która go realizuje (mogą to być te same osoby), nie zna uprzednio, tzn. przed przeprowadzeniem losowej procedury, jej wyniku. Natomiast proces jest losowy w sensie czysto epistemicznym wtedy i tylko wtedy, kiedy żadna z osób, których on dotyczy, a także żadna z osób, która go realizuje (mogą to być te same osoby), nie zna uprzednio, tzn. przed jego przeprowadzeniem, wyniku losowej procedury, i błędnie wierzy, nie będq̨c jednak wprowadzonq $w$ btąd, że prawdopodobieństwa wyników generowanych przez tę procedurę odpowiadają sile ich roszczeń28. Otóż nie ulega wątpliwości, że w przypadku RP losowość musi mieć zawsze charakter statystyczny, tzn. szanse (w sensie częstościowym) pojawienia się określonych wyników loterii powinny rzeczywiście odpowiadać sile roszczeń poszczególnych kandydatów, a nie tylko być uznawane przez jej uczestników za takie (tj. proporcjonalne do siły ich roszczeń). Gdyby spełniony był wyłącznie ten drugi warunek, a więc RP miała charakter czysto epistemiczny, podważałoby to sam jej sens - dawania wyrazu różnej sile roszczeń sprawcy - i każdy z kandydatów dowiedziawszy się o nierzetelności procedury, mógłby zasadnie odmówić akceptacji jej wyniku (uczyniłoby to z pewnością także wielu „zwycięskich” kandydatów pragnących, aby ich zwycięstwo było uczciwe). Analogiczny argument można sformułować także w odniesieniu do RE. Można jednak sądzić, że wymóg losowości w sensie statystycznym ma charakter mniej rygorystyczny w przypadku RE uzasadnionej R1 lub RE uzasadnionej R2. W tych sytuacjach roszczenia kandydatów nie są bowiem równe w tym sensie, w jakim są równe przy R3; są raczej uznane za równe (przy R1 nie ma kryterium sprawiedliwości, natomiast przy R2 kryteria takie występują, są jednak niewspółmierne). Teoretycznie więc kandydaci mogliby przyjąć, że istnieje jakaś sprawiedliwa, nieegalitarna dystrybucja, której znalezienie leży poza możliwościami poznawczymi człowieka. W rezultacie być może łatwiej przyszłoby im zaakceptować wynik procedury czysto epistemicznej, tj. takiej, którą błędnie, ale nie będąc wprowadzonymi w błąd, uznali za egalitarnąa ${ }^{29}$.

Po piąte, Jon Elster (1987, s. 110) trafnie podkreślał, że przejawiamy niechęć do stosowania randomizacji $w$ decyzjach dystrybucyjnych. Twierdził, że wynika to przede wszystkim z dwóch powodów: poczucia, że metoda randomizacji nie licuje z powagą wyboru, oraz z niechęci do przyznania się do ignorancji - zawsze pragniemy dysponować racjonalnymi argumentami za podjęciem określonej decyzji. Zdanie się na przypadek wydaje się, jak ujmuje to Elster (1987, s. 129), „abdykacją rozumu”, której dokonanie przychodzi nam z trudem. Należy jednak dodać, uzupełniając roz-

28 Nieco inne typologie randomizacji można znaleźć np. u Samahy (2009) czy Wassermana (1996).

29 Można sobie wyobrazić także inną sytuację: kandydaci do otrzymania określonego dobra uczestniczący w RE wiedzą, że dany mechanizm jest nierzetelny (np. ścianki kostki są obciążone), ale wybór tego, komu dana ścianka przypadnie, dokonuje się za pomocą kostki rzetelnej. Tego rodzaju dwuetapowa loteria jest oczywiście nieproblematyczna: jej egalitaryzm jest gwarantowany przez egalitaryzm na jej pierwszym etapie. Por. na temat tego rodzaju wieloetapowych loterii zwłaszcza Kornauser \& Stager (1988) oraz Wasserman (1996). 
ważania Elstera, że „abdykacja rozumu” może się wydawać, od strony psychologicznej, dalej idąca w przypadku RE, zwłaszcza uzasadnionej R1 lub R2, niż w przypadku RP. Zauważmy bowiem, że w tych dwóch pierwszych odmianach RE „rozum” dokonuje „abdykacji” nie tylko (jak w przypadku każdej randomizacji) na etapie realizacji samej losowej procedury, ale już na etapie analizy kryteriów: okazuje się bowiem, że albo ich nie ma, albo nie sposób określić stopnia ich spełnienia. Rozum musi więc tutaj niejako „abdykować” dwukrotnie. Inaczej jest w przypadkach RP i RE uzasadnionej R3, w których „abdykacja rozumu” występuje jedynie na etapie realizacji losowej procedury; etap wcześniejszy - (udanego) stwierdzenia stopnia spełniania przez kandydatów kryterium sprawiedliwości (równego przy RE i nierównego przy RP) - jest „przesycony” rozumem. Można więc przypuszczać, że gdyby (kontrfaktycznie) jedynym czynnikiem wpływającym na poziom akceptacji danej procedury losowej był stopień abdykacji rozumu, RP i RE uzasadniona za pomocą R3 byłyby bardziej akceptowalne niż RE uzasadniona za pomocą R1 lub R2.

\section{RANDOMIZACJA EGALITARNA, RANDOMIZACJA PROPORCJONALNA}

\section{A TZW. Number Problem}

Przyjętym milcząco założeniem moich dotychczasowych analiz była teza, że w kontekście danego problemu dystrybucji niepodzielnego dobra/ciężaru można rozważać albo zastosowanie RE, albo RP, ale nie obu metod losowej dystrybucji równocześnie. Założenie to jest generalnie (tj. dla większości problemów dystrybucji niepodzielnych dóbr/ciężarów) trafne. Można jednak wyobrazić sobie takie sytuacje, w których spór będzie dotyczył nie tego, czy można zastosować określona metodę losowej dystrybucji, lecz tego, której z nich należy użyć. Najbardziej znaną sytuacją tego rodzaju, szeroko dyskutowaną w literaturze, jest (wspomniany już w punkcie 1) tzw. Number Problem, dotyczący istotności kryterium liczbowego przy decyzjach dotyczących „życia i śmierci”, tj. wyboru osób, którym należy uratować życie w sytuacji, w której nie można ocalić wszystkich. Warto zbadać go nieco dokładniej.

Wyobraźmy sobie, że dwie wyspy, A i B, zagrożone są tsunami, a ekspedycja ratunkowa może ewakuować mieszkańców tylko jednej z nich. Na wyspie A mieszka 1 osoba, a na wyspie B - 5 osób (jest to wariant kazusu przedstawionego w Taurek, 1977). Załóżmy, że kierownik ekspedycji uznaje kryterium utylitarystyczne (maksymalizacji liczby uratowanych osób) za niewłaściwe. Racje, które skłaniają go do odrzucenia tego kryterium, mogą być różnorakie. Może np. uważać, że narusza ono zasadę równego szacunku dla każdej osoby lub że jest oparte na błędnym założeniu 
o możliwości „agregacji” osób ${ }^{30}$. W tym ostatnim względzie może kierować się np. argumentem zaproponowanym przez Johna Taureka (1977), iż na możliwą utratę życia przez daną osobę można spojrzeć wyłącznie z indywidualnej perspektywy tej właśnie osoby, co wyklucza przyjęcie bezstronnego ujęcia dopuszczającego agregację uratowanych (czy nieuratowanych) istnień różnych osób, nie ma bowiem żadnej osoby, która doświadczałaby tego rodzaju („zagregowanej”) straty ${ }^{31}$. Załóżmy także, że odrzucamy inne niż utylitarystyczna procedury nielosowe, np. procedurę polegającą na "substituting equivalents”, tj. na wzajemnym "neutralizowaniu” roszczeń: jedna osoba z wyspy B neutralizuje niejako roszczenie osoby z wyspy A, co oznacza, że ostatecznie wyspa A nie ma żadnego roszczenia, a wyspa B ma ich cztery (por. Kamm, 1993, s. 10, i krytycznie Broome, 1998). Pozostają więc procedury losowe. Którą z nich - RE czy RP - należy zastosować?

John Taurek uważa, że należy przyjąć RE, ponieważ daje ona każdej zagrożonej osobie równq szansę uratowania ${ }^{32}$. Konstruuje ją jednak dość osobliwie: proponuje rzut monetą - jeśli wypadnie "reszka”, ekspedycja ratuje osobę uwięzioną na wyspie A, natomiast jeśli wypadnie „orzeł”, ekspedycja ratuje osoby uwięzione na wyspie B. W tej loterii każda osoba ma rzeczywiście równą (50\%) szansę uratowania, niemniej nie uwzględnia ona istotnego faktu, że uratowanie dowolnej osoby z wyspy B oznacza uratowanie pozostałych; przyznawanie uwięzionym na wyspie „równych” szans w sposób, jaki proponuje Taurek, pomija więc specyficzny charakter tej sytuacji decyzyjnej.

30 Na marginesie można wspomnieć także o innym możliwym argumencie za niemożliwością agregacji (nieprzywoływanym przez Taureka), a odwołującym się do żydowskiej tradycji etycznej. Według niej przyjmowany jest nie-utylitarystyczny pogląd, iż ten, kto zabija/nie ratuje jednego człowieka, zabija/nie ratuje niejako całego świata, a kto ratuje jednego człowieka, ratuje niejako cały świat. Pogląd ten jest w szczególności zwrócony przeciw takiemu (właśnie utylitarystycznemu) sposobowi myślenia, który pozwala poświęcić życie człowieka w celu uratowania większej liczby istnień ludzkich. U jego podstaw wydaje się leżeć założenie, że w kontekście ratowania najcenniejszego dobra, jakim jest życie, liczby nic nie znaczq, ponieważ z uwagi na nieskończonq wartość pojedynczego życia ludzkiego jedno życie jest warte nie mniej niż ich większa liczba (w obu przypadkach mamy do czynienia z wartością nieskończona). Zauważmy, że pogląd ten może uzasadniać nie tylko propozycję Taureka zastosowania RE w badanym przez niego kazusie, ale także pogląd bardziej radykalny: że nie należy ratować nikogo, gdyż ratowanie oznaczałoby intencjonalne poświęcenie życia co najmniej jednej osoby dla dobra innych osób czy innej osoby.

31 Taurek wysuwa jeszcze inny argument, który można zrekonstruować następująco. Przesłankami są dwie normy: osoba z wyspy A miałaby prawo (gdyby miała taką możliwość) ratować siebie, poświęcając osoby z wyspy B; osoba bliska osobie z wyspy A miałaby prawo (gdyby miała taką możliwość) ją ratować, poświęcając osoby z wyspy B. A zatem (wniosek) także osoba obca osobie z wyspy A miałaby prawo (gdyby miała taką możliwość) ją ratować, poświęcając osoby z wyspy B. Argument ten jest jednak w sposób oczywisty wadliwy; wydaje się bowiem, że moralne obowiązki osoby $\mathrm{O}$ wobec siebie i osoby bliskiej osobie $\mathrm{O}$ wobec osoby O mogą być inne niż moralne obowiązki osoby obcej osobie O wobec osoby O. Nie ma więc żadnej sprzeczności w przyjęciu przesłanek i odrzuceniu wniosku argumentu Taureka; wniosek ten bowiem logicznie z nich nie wynika.

32 Taurek dodaje, że gotów byłby zastosować tego rodzaju loterię także wówczas, gdyby na wyspie B było dużo więcej osób, np. 50. 
Bardziej przekonująca, przynajmniej na pierwszy rzut oka, wydaje się być tutaj RP, przy czym możliwe są jej różne interpretacje/sposoby opisania. Wedle pierwszej interpretacji, kierownik ekspedycji rzuca kostką, z której pięć ścianek „sprzyja” decyzji o ratowaniu osób z wyspy B, a jedna ścianka - decyzji o ratowaniu osoby z wyspy A. Interpretacja ta jest jednak narażona na poważny zarzut: oznacza ona w istocie, że każdej osobie z wyspy B przyznawana jest waga 5/6, co narusza wymóg sprawiedliwości ex ante $e^{33}$. Wedle drugiej interpretacji, każda osoba utrzymuje identyczną „wagę" (1/6), przy czym jeśli wylosowana zostaje osoba z wyspy B, po jej uratowaniu członkowie ekspedycji mają obowiązek ruszenia na pomoc pozostałym. Jens Timmermann, który proponuje tę interpretację, nazywa taką loterię „indywidualistyczną” i podkreśla, że choć jest ona praktycznie równoważna loterii proporcjonalnej (w kontekście analizowanego przez niego Number Problem), to jednak w warstwie filozoficznej jest odmienna, ponieważ traktuje osoby z wyspy B „oddzielnie” - właśnie „indywidualistycznie" - natomiast loteria proporcjonalna traktuje je niejako łącznie (przypisując im jako grupie wagę 5/6). Trudno zaprzeczyć, że status tej „indywidualistycznej” loterii jest niejasny. Z jednej bowiem strony może być ona, jak się wydaje, traktowana jako loteria proporcjonalna (jako jej szczególna interpretacja). Z drugiej strony jednak może być także interpretowana jako loteria egalitarna, która - z uwagi na specyficzne warunki sytuacji dystrybucyjnej (przydzielenie dobra „wybranej” w loterii osobie oznacza automatycznie jego przydzielenie innym osobom) - prowadzi do identycznych wyników jak loteria proporcjonalna. Okazuje się więc, że w pewnych sytuacjach nie tylko może pojawić się dylemat, czy należy stosować RE, czy RP, ale oba typy randomizacji mogą być także praktycznie równoważne lub też trudne do rozróżnienia.

Nasuwa się jednak kluczowe pytanie: Czy zastosowanie randomizacji w kontekście Number Problem jest w ogóle zasadne? W moim przekonaniu nie jest. Jeśli chodzi o RE (w wersji Taureka), pomija ona, jak już wspomniałem, moralnie istotną osobliwość dokonywanej w Number Problem dystrybucji, polegającą na tym, że dystrybucja ta nie jest „niezależna” - przyznanie dobra określonej osobie pociąga za sobą przyznanie go pozostałym. Zaś co do RP, w Number Problem nie jest spełniony żaden z dwóch warunków, który (co najmniej jeden) musi być, jak argumentowałem w punkcie 3, spełniony, aby można było odwołać się do RP: problem dystrybucji dobra (jakim jest uratowanie życie) nie jest powtarzany (przynajmniej w przypadku osób, które nie miały szczęścia przy pierwszej dystrybucji), zaś różnica w sile „roszczeń” obu grup do uzyskania pomocy jest istotna. Można jednak także sformułować inne argumenty przeciw stosowaniu RP w kontekście Number Problem. Wskażę na dwa, które wydają mi się szczególnie interesujące. Pierwszy formułuje Iwao Hirose (2007), który zauważa, że stosując RP jako rozwiązanie Number Problem, możemy

33 Zarzut ten formułuje np. Gerald Lang (2005); zamiast pojęcia „sprawiedliwości ex ante” stosuje pojęcie „selection fairness"; są one jednak, jak wspomniano, równoznaczne. 
albo zapytać: „Kogo należy uratować?”, albo: „Kogo nie należy uratować?”. W pierwszym przypadku otrzymujemy intuicyjną wersję RP (przyznającą wyższe prawdopodobieństwo uratowania osobom przebywającym na bardziej zaludnionej wyspie), w drugim - pewien paradoksalny rodzaj RP, który Hirose nazywa „inverse weighted lottery", prowadzący do przyznania osobom z liczebniejszej wyspy wyższego prawdopodobieństwa nieuratowania (jeśli każdej z osób zagrożonych tsunami przyznajemy równe prawdopodobieństwo nieuratowania, wynoszące $1 / 6$, to prawdopodobieństwo nieuratowania dowolnej osoby z wyspy B wyniesie 5/6). Wydaje się, że Hirose rzeczywiście ma rację, iż w kontekście Number Problem nie ma żadnych racjonalnych powodów, aby pytanie formułować raczej w jeden niż w drugi sposób ${ }^{34}$. Drugi argument przeciw stosowaniu loterii w Number Problem sformułował Thomas Scanlon, pisząc, iż „nie ma żadnych racji, aby na tym etapie ponownie tasować, przez wprowadzenie ważonej czy równej loterii, moralną talię" (Scanlon, 2000, s. 234). Innymi słowy, zdaniem Scanlona "los” odegrał już swoją rolę, dokonując „bezstronnie” (bo bez żadnego związku z przyszłym wydarzeniem, jakim okazało się tsunami) takiej a nie innej „dystrybucji” miejsc na wyspach, która, właśnie z uwagi na swą bezstronność, powinna być uznana za sprawiedliwą; zastosowanie metody losowej byłoby więc „ponownym tasowaniem moralnej talii (reshuffling the moral deck)", a więc zakładałoby (milcząco i btędnie), że owa pierwotna dystrybucja osób (ich rozmieszczenie na obu wyspach) była niesprawiedliwa. Argument Scanlona został ciekawie zreinterpretowany w kategoriach oczekiwanych szans uratowania (por. Saunders, 2009, s. 282, oraz Rasmussen, 2012, s. 213). Otóż jeśli nie tasujemy ponownie moralnej talii (tj. nie stosujemy randomizacji w kontekście decyzji o udzieleniu pomocy), kierując się zasadą maksymalizacji uratowanych istnień, prawdopodobieństwo uratowania dla każdej z osób wynosi 5/6 (takie jest bowiem prawdopodobieństwo znalezienia się w grupie liczniejszej). Jeśli natomiast stosujemy randomizację (proporcjonalną), wtedy prawdopodobieństwo to zmniejsza się do 13/18 (1/6 1/6 + 5/6 5/6). Rzecz jasna, kwestią sporną jest to, na ile zasadne jest interpretowanie umiejscowienia na danej wyspie za wynik pewnej „naturalnej loterii”, i to loterii moralnie istotnej.

Podsumowując, metody losowe nie są w kontekście Number Problem właściwymi metodami dystrybucji. Nie będę natomiast rozstrzygał kwestii, która z przedstawionych wyżej metod nielosowych jest w tym ujęciu najwłaściwsza (czy metoda maksymalizacji uratowanych istnień, czy też metoda „substituting equivalents”).

34 Należy jednak dodać, że zarzutu Hirose nie można traktować jako ogólnego zarzutu przeciw stosowaniu RP w dystrybucji dóbr/ciężarów (Hirose nie interpretuje go zresztą w ten sposób; nie pyta jednak także o jego „uniwersalność”); dotyczy on, jak się wydaje, wyłącznie Number Problem. Rozważmy bowiem jakiś inny (typowy) problem dystrybucji niepodzielnego dobra $x$. Załóżmy, że kryterium jego dystrybucji jest spełniane przez dwóch kandydatów w różnym stopniu: osoba A spełnia je w mniejszym stopniu (20 punktów), niż osoba B (40 punktów). Siła roszczenia osoby A do otrzymania dobra jest więc równa $1 / 3$, a osoby B $-2 / 3$. Jeśli pytanie o właściwą dystrybucję postawimy w sposób negatywny - „komu nie należy przyznać dobra” nikt nie będzie miał wątpliwości, że wartości te należy odwrócić (pierwotnie bowiem były dostosowane do pozytywnej wersji pytania). 


\section{Podsumowanie}

Na zakończenie zestawię główne konkluzje moich rozważań, zwłaszcza dotyczące warunków dopuszczalności stosowania RE i RP; pominę różnego rodzaju ustalenia poboczne. Konkluzje te można ująć tak oto:

1) Racje sprawiedliwościowe za stosowaniem RE należy rozumieć szeroko, obejmując tym pojęciem nie tylko sytuacje indyferencji - równego spełniania kryterium podziału - ale także braku kryteriów podziału lub ich niewspółmierności. Wystąpienie tych racji sprawia, że RE jest nie tylko dopuszczalna, ale i wymagalna.

2) Racje sprawiedliwościowe są silniejsze niż utylitarystyczne, tj. takie, które z uwagi na pozytywny bilans korzyści i strat nakazują stosowanie w danej sytuacji dystrybucyjnej RE, mimo iż w świetle relewantnego dla tej sytuacji kryterium sprawiedliwości dystrybucja powinna być nieegalitarna. Racje utylitarystyczne uzasadniają zastosowanie RE tylko wyjątkowo, tzn. wyłącznie wtedy, gdy wynikająca z niego przewaga korzyści nad kosztami jest szczególnie duża.

3) Z uwagi na konflikt między sprawiedliwością ex ante i ex post, który może przybrać ostrą postać tylko w kontekście RP, RP może być stosowana stosunkowo rzadko - wyłącznie w dwóch sytuacjach: wielokrotnej powtarzalności dystrybucji i/lub zachodzenia niewielkiej różnicy w roszczeniach kandydatów do danego dobra/ciężaru, przy czym nawet w tych sytuacjach RP jest, jak się wydaje, wyłącznie dopuszczalna, a nie wymagalna.

4) Jednorazowa (proporcjonalna) loteria rozwarstwiona jest bardziej sprawiedliwa niż jednorazowa (proporcjonalna) loteria nierozwarstwiona. Natomiast jednorazowa (proporcjonalna) loteria rozwarstwiona wydaje się mniej sprawiedliwa niż powtarzana (proporcjonalna) loteria nierozwarstwiona: o ile pierwsza wymusza wystąpienie (umiarkowanej) niesprawiedliwości ex post, o tyle druga, przy odpowiednio dużej liczbie powtórzeń, wyklucza pojawienie się niesprawiedliwości ex post.

5) RP musi mieć zawsze charakter statystyczny, natomiast RE może mieć niekiedy charakter epistemiczny.

6) Omówienie Number Problem pozwoliło wzbogacić prowadzoną w niniejszym artykule analizę porównawczą RE i RP, ujawniło bowiem dwa nieoczywiste fakty: (a) iż istnieją takie problemy dystrybucyjne, w których, przynajmniej prima facie, zarówno RE, jak i RP wydają się dopuszczalne; i (b) w których można mieć wątpliwości, czy dany mechanizm losowy jest w istocie RE, czy RP. Jeśli chodzi o fakt (a), argumentowałem jednak, że ta dopuszczalność ma wytacznie charakter prima facie: ani RE, ani RP nie są w kontekście Number Problem właściwymi metodami dystrybucji. 


\section{Bibliografia}

Bożykowski, M. (2012). Probabilistyczne metody podziału zbioru dóbr niepodzielnych. Decyzje, 26, 59-107.

Broome, J. (1984). Selecting People Randomly. Ethics, 95(1), 38-55.

Broome, J. (1990). Fairness. Proceedings of the Aristotelian Society, 91, 87-101.

Broome, J. (1998). Kamm on Fairness. Philosophy and Phenomenological Research, 58, 955-961.

De Coulanges, F. (1882). The Ancient City: A Study on the Religion, Laws and Institutions of Greece and Rome. Przeł. W. Small. Boston: Lee and Shepard, New York: Charles T. Dillingham.

Dowlen, O. (2008). The Political Potential of Sortition. Exeter: Imprint Academic.

Duxbury, N. (1999). Random Justice: On Lotteries and Legal Decision-Making. Oxford: Clarendon Press.

Eliaz, K., Rubinstein, A. (2014). On the Fairness of Random Procedures. Economic Letters, 123(2), 168-170.

Elster, J. (1987). Taming Chance: Randomization in Individual and Social Decisions. http://tannerlectures.utah.edu/_documents/a-to-z/e/Elster88.pdf, 107-179.

Feinberg, S.E. (1971). Randomization and Social Affairs: The 1970 Draft Lottery. Science, 171, 255-261.

Fishkin, J.S. (1984). Justice, Equal Opportunity, and the Family. New Haven: Yale University Press.

Fishkin, J.S. (1991). Democracy and Deliberation: New Directions for Democratic Reform. New Haven: Yale University Press.

Goodwin, B. (2005). Justice by Lottery. Charlottesville: imprint-academic.

Hirose, I. (2007). Weighted Lotteries in Life and Death Cases. Ratio 20, 45-56.

Kamm, F.M. (1993). Morality, Mortality, Vol. I: Death and Whom to Save From It. Oxford: Oxford University Press.

Komhauser, L.A., Sager, L.G. (1988). Just Lotteries. Rationality and Society, 27, 483-516.

Lang, G. (2005). Fairness in Life and Death Cases. Erkenntnis, 62, 321-351.

Lissowski, G. (1992). Probabilistyczny podział dóbr. Prakseologia, 3-4(116-117), 149-165.

Lissowski, G. (1994). Ustalanie sposobu podziału dóbr w sytuacji eksperymentalnej. Studia socjologiczne, 3-4(134-135), 173-216.

Lissowski, G. (2006a). Losowe metody podejmowania decyzji społecznych a etyka. Decyzje, 5, 101-108.

Lissowski, G. (2006b). Probabilistyczne zasady równości Klemensa Szaniawskiego. Decyzje, 6, 5-32.

Machiavelli, N. (1993). Rozważania nad pierwszym dziesięcioksięgiem Historii Rzymu Liwiusza.

W: N. Machiavelli, Ksiaże; Rozważania. Przeł. K. Żaboklicki. Warszawa: „Verum”, 133-388.

Perelman, Ch. (1963). Justice et raison. Bruxelles: Presses Universitaires de Bruxelles.

Peyton Young, H. (1995). Equity. In Theory and Practice. Princeton, New Jersey: Princeton University Press.

Rassmussen, K.M. (2012). Should the probabilities count? Philosophical Studies: An International Journal for Philosophy in the Analytic Tradition, 159(2), 205-218.

Rawls, J. (1971). A Theory of Justice. Cambridge, Mass., London, England: Harvard University Press. 
Rosenberg, D., Shavell, S. (2005). A Simple Proposal to Halve Litigation Costs. Virginia Law Review, 91(7), 1721-1735.

Samaha, A.M. (2009). Randomization and Adjudication. William \& Mary Law Review, 51(1), 1-87.

Scanlon, T. (2000). What We Owe to Each Other. Cambridge, Mass., London, England: Harvard University Press.

Saunders, B. (2008). The Equality of Lotteries. Philosophy, 83(325), 359-372.

Saunders, B. (2009). A Defence of Weighted Lotteries in Life Saving Cases. Ethical Theory and Moral Practice, 12(3), 279-290.

Schoeck, H. (1987, 1969). Envy. A Theory of Social Behaviour. Indianapolis: Liberty Press.

Stone, Peter (2009). The Logic of Random Selection. Political Theory, 37(3), 375-397.

Szaniawski, K. (1966). O pojęciu podziału dóbr. Studia Filozoficzne, 2(45), 61-72.

Szaniawski, K. (1975). Formal Analysis of Evaluative Concepts. International Social Science Journal, 3(27), 446-457.

Szaniawski, K. (1979). On Formal Aspects of Distributive Justice. W: Saarinen, E., Hilpinen, R. (red.), Essays in Honour of Jaakko Hintikka on the Occasion of Fiftieth Birthday on January 12, 1979. Dordrecht-Holland: D. Reidel, 135-146.

Taurek, J.M. (1977). Should the Numbers Count? Philosophy and Public Affairs, 6(4), 293-316.

Timmermann, J. (2004). The Individualist Lottery: How People Count, But Not Their Number. Analysis, 64(2), 106-112.

Wasserman, D. (1996). Let them Eat Chances: Probability and Distributive Justice. Economics and Philosophy 12(1), 29-49.

Young, M. (1961). The Rise of the Meritocracy 1870-2033: An Essay on Education and Society. London: Penguin Books.

Załuski, W. (2014). Two Concepts of Formal Justice. W: Stelmach, J., Brożek, B. (red.), Studies in the Philosophy of Law, Vol. 8. Foundations of Legal Negotiations. Kraków: Copernicus Center Press, 11-25. 